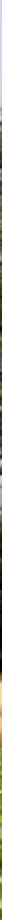

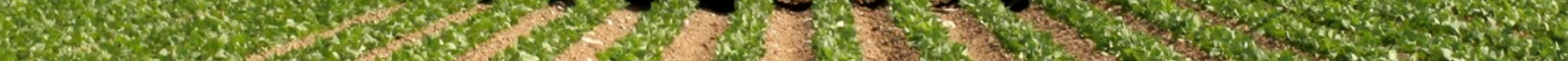

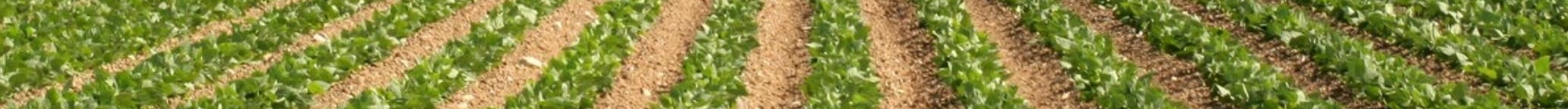

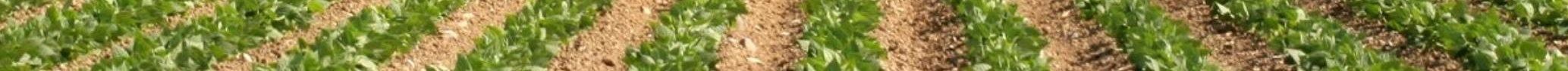

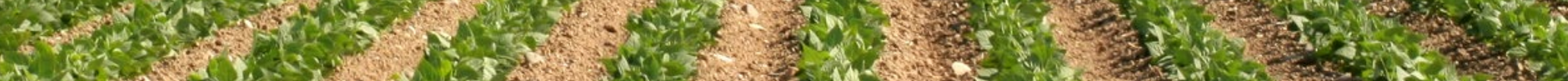
4.

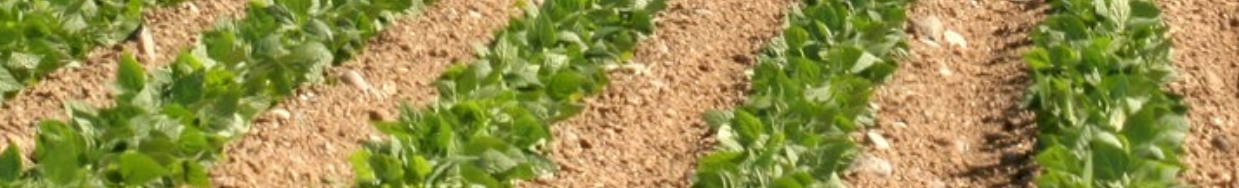

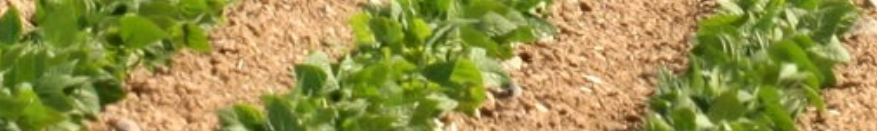

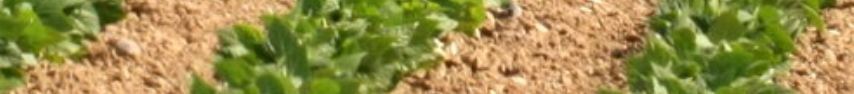

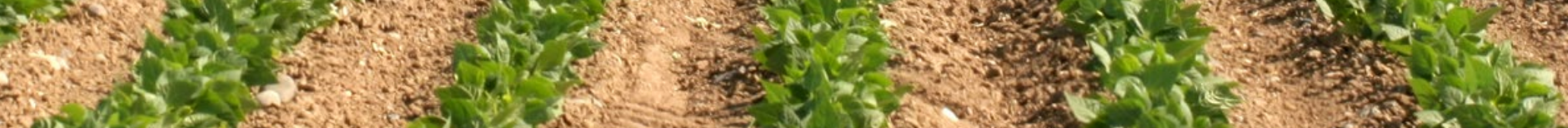
II

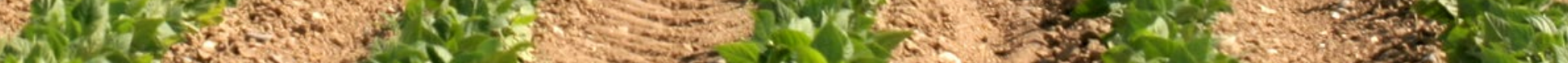

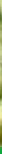

\title{
User manual for FOCUSSPIN version 3.3
}

D. van Kraalingen, F. van den Berg, E.L. Wipfler, W.H.J. Beltman, 

User manual for FOCUSSPIN version $\mathbf{3 . 3}$ 
This WOt-technical report was produced in accordance with the Quality Management System of the Statutory Research Tasks Unit for Nature \& the Environment, part of Wageningen University \& Research.

The mission of the Statutory Research Tasks Unit for Nature and the Environment (WOT Natuur \& Milieu) is to carry out statutory research tasks on issues relating to nature and the environment. These tasks are implemented in order to support the Dutch Minister of Agriculture, Nature and Food Quality, who is responsible for these issues. We provide data about agri-environment, biodiversity and soil information to compile reports as part of national and international obligations, and we work on products of the PBL Netherlands Environmental Assessment Agency, such as the Assessment of the Human Environment reports.

\section{Disclaimer WOt-publicaties}

The 'WOt-technical reports' series presents the findings of research projects implemented for the Statutory Research Tasks Unit for Nature \& the Environment by various centres of expertise.

WOt-technical report 169 presents the findings of a research project funded by the Dutch Ministry of Agriculture, Nature and Food Quality (LNV). 


\section{User manual for FOCUSSPIN version 3.3}

D. van Kraalingen ${ }^{1}$, F. van den Berg ${ }^{1}$, E.L. Wipfler ${ }^{1}$, W.H.J. Beltman ${ }^{1}$, M.M.S. ter Horst ${ }^{1}$, J.A. te Roller ${ }^{1}$

1 Wageningen Environmental Research

Project WOT-04-008-024

Statutory Research Tasks Unit for Nature \& the Environment

Wageningen, September 2020

WOt-technical report 169

ISSN 2352-2739

DOI: $10.18174 / 521726$ 


\begin{abstract}
Van Kraalingen, D., E.L. Wipfler, F. van den Berg, W.H.J. Beltman, M.M.S. ter Horst \& J.A. te Roller (2020). User manual for FOCUSSPIN version 3.3. Wageningen, The Statutory Research Tasks Unit for Nature \& the Environment (WOT Natuur \& Milieu). WOt-technical report 169. 38 pp; 25 Figs; 1 Tab; 7 Refs.

In the EU and Dutch national registration procedures for plant protection products, fate models and scenarios are being used to assess the environmental risks of these products. For each model application, data on the physico-chemical properties of the substances are required. The software tool SPIN has been developed to store substance properties in a common database that can be accessed by the different model applications. This facilitates the use of these model applications for a specific substance. This user manual describes the use of FOCUSSPIN version 3.3, that can be used in combination with the EU FOCUS models (leaching to groundwater and exposure in surface water). FOCUSSPIN version 3.3. can also be used in combination with the new versions of national exposure assessment tools GeoPEARL (leaching to groundwater), DROPLET (drinking water) as well as the current version of GEM 3.3.2 (emission from greenhouses).
\end{abstract}

Keywords: crop protection product, DROPLET, environmental fate, exposure assessment tools, FOCUS models, GeoPEARL, GEM, physico-chemical properties, pesticide, substance properties

\title{
Referaat
}

Van Kraalingen, D., E.L. Wipfler, F. van den Berg, W.H.J. Beltman, M.M.S. ter Horst \& J.A. te Roller (2020). Gebruikershandleiding voor FOCUSSPIN versie 3.3. Wettelijke Onderzoekstaken Natuur \& Milieu, WOttechnical report 169. 38 blz..; 25 fig; 1 tab; 7 ref.

In de Europese en Nederlandse nationale toelatingsprocedure voor gewasbeschermingsmiddelen worden modellen en scenario's gebruikt om de milieurisico's van deze producten te beoordelen. Voor elke modeltoepassing zijn gegevens over de fysisch-chemische eigenschappen nodig. De softwaretool SPIN is ontwikkeld voor de opslag van stofeigenschappen in een gedeelde database, die door de verschillende modeltoepassingen gebruikt kan worden. Dat vergemakkelijkt het gebruik van deze modeltoepassingen voor een specifieke stof. Deze gebruikershandleiding beschrijft de toepassing van FOCUSSPIN versie 3.3, die gebruikt kan worden in combinatie met de EU FOCUS-modellen (uitspoeling naar grondwater en blootstelling in oppervlaktewater). FOCUSSPIN versie 3.3 kan ook gebruikt worden in combinatie met de nieuwe versies van de nationale blootstellingsinstrumenten GeoPEARL (uitspoeling naar grondwater), DROPLET (drinkwater) en de huidige versie van GEM 3.3.2 (emissie vanuit kassen).

Trefwoorden: gewasbeschermingsmiddel, DROPLET, lotgevallen, instrumenten beoordeling blootstelling, FOCUS-modellen, GeoPEARL, GEM, fysisch-chemische eigenschappen, pesticide, stofeigenschappen

\section{Photo cover: Sascha Burkard}

\section{(C) $2020 \quad$ Wageningen Environmental Research}

PO Box 47, 6700 AA Wageningen

Phone: (0317) 4807 00; erik.vandenberg@wur.nl

The Statutory Research Tasks Unit for Nature and the Environment (WOT Natuur \& Milieu; an unit under the auspices of the Stichting Wageningen Research), PO Box 47, NL 6700 AA Wageningen, T +31 3174854 71, info.wnm@wur.nl, www.wur.nl/wotnatuurenmilieu. WOT Natuur \& Milieu is part of Wageningen University \& Research.

This report can be downloaded free of charge from https://doi.org/10.18174/521726 or from www.wur.nl/wotnatuurenmilieu. WOT Natuur \& Milieu provides no printed copies of reports.

- Acquisition, duplication and transmission of this publication is permitted with clear acknowledgement of the source.

- Acquisition, duplication and transmission is not permitted for commercial purposes and/or monetary gain.

- Acquisition, duplication and transmission is not permitted of any parts of this publication for which the copyrights clearly rest with other parties and/or are reserved.

WOT Natuur \& Milieu assumes no liability for any losses resulting from the use of the research results or recommendations in this report. 


\section{Preface}

For the environmental fate of plant protection products according to EU regulation 2009/1107 different fate models are used to assess the leaching to groundwater and the exposure of aquatic organisms for concentrations in surface waters. For each of these model applications, data on the physico-chemical properties are required. To facilitate the use of these models, a central database for storing the data on the physico-chemical properties of substance has been developed. This database can be used in combination with the FOCUS models for groundwater and surface water as well as with the models that have been in adopted for the evaluation of the environmental fate according to the authorization procedure in the Netherlands.

In 2013 the user manual for SPIN version 1.1 has been released. This first version of SPIN could be used in combination with the FOCUS Surface Water step 3 models, i.e. FOCUSSWASH, FOCUSMACRO, FOCUSPRZM and FOCUSTOXSWA. Recently a new version of SPIN has been developed to support its use in combination with FOCUSPEARL for the assessments at the EU level, GeoPEARL for the national assessment of the leaching to groundwater and GEM for the assessment of the environmental risks of crop protection products applied in greenhouse systems. In addition, the new SPIN version (released as FOCUSSPIN version 3.3) can also be used in combination with DROPLET, a software tool to evaluate the risk of the use of plant protection products for drinking water production from surface waters.

Daniel van Kraalingen, Erik van den Berg and Louise Wipfler Wageningen, April 2020 



\section{Contents}

$\begin{array}{lr}\text { Preface } & 5 \\ \end{array}$

$\begin{array}{lr}\text { Summary } & 9\end{array}$

$\begin{array}{lr}\text { Samenvatting } & 11\end{array}$

1 Introduction $\quad 13$

$\begin{array}{lll}1.1 & \text { Release versions of FOCUSSPIN } & 13\end{array}$

1.2 Installation $\quad 14$

$\begin{array}{lll}1.3 & \text { Compatibility } & 14\end{array}$

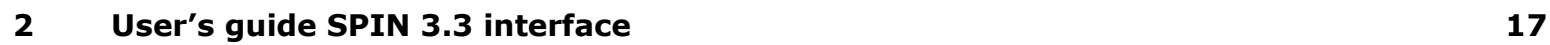

$\begin{array}{lll}2.1 & \text { Management of substances } & 18\end{array}$

$\begin{array}{lll}2.2 & \text { Creating a substance } & 18\end{array}$

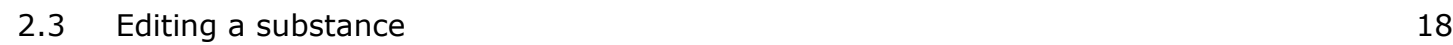

2.3.1 General tab 19

$\begin{array}{ll}2.3 .2 \text { Sorption tab } & 19\end{array}$

2.3.3 Transformation tab $\quad 23$

$\begin{array}{ll}\text { 2.3.4 Crop processes tab } & 26\end{array}$

\begin{tabular}{ll}
2.4 & Creating metabolite schemes \\
\hline
\end{tabular}

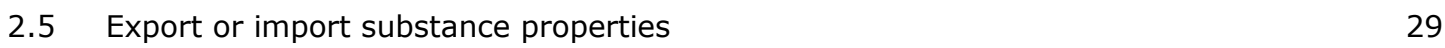

2.5.1 Data export $\quad 30$

$\begin{array}{ll}\text { 2.5.2 Data import } & 30\end{array}$

$\begin{array}{lr}\text { References } & 33\end{array}$

$\begin{array}{lr}\text { Justification } & 35\end{array}$ 



\section{Summary}

This is the user manual for the Substance Plug IN tool, SPIN 3.3. This version can be used with FOCUS_SWASH 5.3, FOCUS_TOXSWA 5.5.3, GEoPEARL 4.4.4, DROPLET 1.3.2 and FOCUSPEARL 5.5.5. This manual addresses the main functionalities of SPIN and how to use them.

SPIN is essentially a database for storing substances with their properties relevant to exposure assessment tools that are listed above, and a graphical user interface to edit these properties and to add new substances to the database. After installation of SPIN and a host-application, for example FOCUS_SWASH, SPIN can be started by clicking on the 'Substances' button on the interface of FOCUS_SWASH. If SPIN is started from a host-application, only the substance properties relevant for the host-application can be edited. SPIN can also be started as a standalone application in which case all substance properties can be edited. Furthermore, SPIN is backward compatible, so all new releases of SPIN can be used in combination with host-applications that have been released earlier in combination with a previous version of SPIN.

The user interface consists of an upper browse part that permits the user to select the substance of interest and a lower part with tabs for the different properties types of the substance. The tabs are organised on the bases of the process-environmental compartment combination, for example sorption in soil, water or sediment and transformation in soil, water and sediment.

For each substance property, the interface provides an entry field with a label and the unit for the value of the property to be entered. After a value has been entered, SPIN checks whether the value for the property entered falls within the range as set in the database for that property. Information buttons provide more detailed information on the properties, such as a description and a specification of the minimum and the maximum value as set in the database for the property.

The database file can be exchanged between users or copied and stored for archiving purposes. The substances and their properties can be exported to files and imported from files with different field separators and decimal separators. 



\section{Samenvatting}

Dit is de gebruikershandleiding voor het Substance Plug IN software instrument, SPIN 3.3. Deze versie kan gebruikt worden met FOCUS_SWASH 5.3, FOCUS_TOXSWA 5.5.3, GeoPEARL 4.4.4, DROPLET 1.3.2 en FOCUSPEARL 5.5.5. Deze gebruikershandleiding behandelt de belangrijkste functionaliteiten van SPIN en op wat voor manier daarvan gebruik te maken is.

SPIN is in essentie een database voor het opslaan van stoffen met hun eigenschappen die relevant zijn voor de blootstellingsinstrumenten die hierboven vermeld staan en een grafische gebruikersinterface voor het wijzigen van de waarden voor deze eigenschappen alsook voor het toevoegen van nieuwe stoffen aan de database. Na de installatie van SPIN en een applicatie die van SPIN gebruik maakt, een zgn. 'gast'-applicatie zoals bijvoorbeeld FOCUS_SWASH, kan SPIN gestart worden door te klikken op de 'Substance' knop op het gebruikersinterface van FOCUS_SWASH. In het geval dat SPIN gestart wordt vanuit een gastapplicatie, dan kunnen alleen die stofeigenschappen gewijzigd worden die relevant zijn voor deze applicatie. SPIN kan ook direct - 'stand-alone' - gestart worden en dan kunnen alle stofgegevens aangepast worden. Tevens is SPIN achterwaarts compatibel, dus alle nieuwe releases kunnen gebruikt worden met eerdere versies van gastapplicaties die zijn uitgebracht in combinatie met een eerdere versie van SPIN.

Het gebruikersinterface bestaat uit een bovendeel voor navigatie dat de gebruiker in staat stelt om de gewenste stof te selecteren en een onderdeel met 4 tabbladen voor de verschillende eigenschapstypen van de stof. Deze tabs zijn ingedeeld op basis van de proces - milieucompartiment combinatie, bijvoorbeeld sorptie in de bodem, water of sediment en omzetting in bodem, water en sediment.

Voor elke stofeigenschap biedt het interface een invulveld met een label en de eenheid voor de waarde van de eigenschap die ingevoerd wordt. Nadat deze waarde is ingevoerd controleert SPIN of deze waarde binnen de range valt van toegestane waarden voor deze eigenschap. Informatieknoppen geven meer uitgebreide informatie over de eigenschappen, zoals een beschrijving en een specificatie van de minimum en maximumwaarde zoals die in de database gehanteerd worden voor deze eigenschap.

Het database-bestand kan uitgewisseld worden met andere gebruikers of gekopieerd dan wel gearchiveerd worden. De stoffen en hun eigenschappen kunnen geëxporteerd worden naar bestanden of geïmporteerd worden vanuit bestanden met gebruik van verschillende symbolen voor de decimaal of onderscheidingsteken. 



\section{Introduction}

In the authorization procedure for the agricultural use of plant protection products the environmental risks must be assessed according to EU regulation 1107/2009. A series of models and scenarios have been developed to do these assessments, ranging from models and scenarios to assess the risk of leaching to groundwater to model suites and scenarios to assess the risks of exposure of aquatic organisms.

In the Netherlands, exposure models addressing specific Dutch environmental conditions and agricultural practices have been implemented in the registration procedure. Such models have been implemented in relation to the risk of leaching to groundwater, the evaluation of the risk of agricultural use of crop protection products on the production of drinking water from surface water as well as the environmental risks due to agricultural use of crop protection products in soil-bound and soilless greenhouse systems.

Model applications used in the EU or Dutch authorization procedure to evaluate the environmental risks require input on substance properties. Entering substance properties for each model application again, and - if relevant - the properties of their metabolites, can be time-consuming and the user needs to check whether the property value for one application is consistent with that for the other application. Therefore, SPIN has been developed to simplify the work of the user of these models and to ensure consistency in substance properties input when using different models for the same substance. More detailed information on the use of these properties in the fate models can be found in the reports describing the model concepts for TOXSWA (Ter Horst et al., 2016) and PEARL (Van den Berg et al., 2016).

SPIN (Substance Plug IN) is an application that enables the creation, editing and archiving of substances with values for all properties required when using the models to assess the exposure of soil organisms, the leaching to groundwater, the exposure of aquatic organisms in surface water systems as well as in paddy-rice systems. SPIN consists of a graphical user-interface and a database; the user interface facilitates access to the database and the interaction with the user. Each substance has a unique code, a name and a label. Substances can be added to the database, either by creating a new substance or by copying an existing substance and modifying the properties. After installation of FOCUSSPIN and a host-application, for example FOCUSSWASH, SPIN can be started by clicking on the 'Substance' button on the interface of FOCUSSWASH. The database can also be exchanged between users or computer systems by copying the database file. The substances and their properties can be exported to files and imported from files with different field separators and decimal separators. This manual describes the use and the functionalities of the software tool FOCUSSPIN 3.3.

\subsection{Release versions of FOCUSSPIN}

The release version of SPIN 3.3, i.e. FOCUSSPIN 3.3, is used in combination with the EU exposure assessment tools FOCUS_SWASH 5.3 (van den Berg et al., 2015), FOCUS_TOXSWA 5.5.3 (Beltman et al., 2018) and FOCUSPEARL 5.5 .5 (van den Berg et al., 2019), which are referred to as 'hostapplications'. The FOCUSSPIN versions can be downloaded from the FOCUS DG SANTE website of the Joint Research Centre in Ispra (Italy) via https://esdac.jrc.ec.europa.eu/projects/spin. The FOCUS DG SANTE website is the one and only definitive source of the currently approved version of the FOCUS scenarios and associated models and input files. On the download tab the latest version of the FOCUSSPIN model as well as older versions of the model can be downloaded.

FOCUSSPIN 3.3. is also used in the Dutch assessment tool GeoPEARL 4.4.4 for the leaching to groundwater, DROPLET 1.3.2 for the evaluation of risks of agricultural use of crop protection products 
for the production of drinking water from surface waters and GEM 3.3.2 for the environmental risk assessment for greenhouse systems.

After starting from a host-application only the properties relevant to this application are editable. The values for the properties of the selected substance are automatically transferred to the hostapplication. SPIN can also be started as a standalone application in which case all substance properties can be edited.

\subsection{Installation}

After downloading FOCUSSPIN 3.3 and extracting the zip file, the installation procedure is started by running the exe file. During the installation procedure the user is asked to specify the installation directory of the application and that of the database. The default directory for installing the SPIN application (being a 32 bits application) is C: \Program Files \PesticideModels $\backslash$ SPIN on a 32-bit platform or C: \Program Files (x86)\PesticideModels \SPIN on a 64-bit platform.

There are two options how to use the SPIN database in case two or more users use the same personal computer: (i) each user has its own SPIN database, or (ii) each user uses the same SPIN database. The first option is proposed by default for installing the SPIN database, the installation directory being [userdocs] \PesticideModels $\backslash$ SPIN, where [userdocs] refers to the user's MyDocuments folder. This directory is only accessible for the user who installed SPIN. If another user on the same PC starts SPIN for the first time, the user will be asked for a location of the SPIN database. On that directory the user will get a personal copy of an empty SPIN database.

If the second option is preferred then change the default data directory to a public directory that is available for every user. In that case all users on the PC will use the same SPIN database.

Please check whether the installation directory is not on a network drive. It should be installed on a local drive, where the user has read/write access.

\subsection{Compatibility}

SPIN is backward compatible, so all new releases of SPIN can be used in combination with hostapplications that have been released earlier in combination with a previous version of SPIN. There is no need to de-install previous versions of SPIN. Upon starting FOCUSSPIN version 3.3 an updating process will take place to ensure the database is converted to the newest standard without loss of substance data stored in the older version of the database. Therefore, no parallel installations of FOCUSSPIN 2.2 and FOCUSSPIN 3.3 are possible. FOCUSSPIN version 3.3 can be installed on Windows 7, Windows 8 and Windows 10.

In the user interface, the substance properties are grouped in tabs according to the processes that they address: General, Sorption, Transformation, and Crop processes. At a lower level, properties are grouped (in sub-tabs) according to compartments in the modelled system (soil, surface water, sediment and substrate (for greenhouse applications)). Each property has an entry field to edit the value, as well a label with a short description and units. Additionally, an information button next to the entry field brings up a pop-up window providing background information on the properties, including the range of acceptable values. After a property value has been entered by the user, SPIN checks whether it falls within this range.

Upon creating a new substance, all property values are empty-i.e. default values are not entered automatically. Default values may differ between host-applications, so the user is e fully responsible for choosing the appropriate values for all properties. When SPIN is opened from a new hostapplication for the first time, example substances are automatically added to the database, which have 
the correct default values as required for the use of the host application. These examples can be copied and modified for easy creation of new substances. 



\section{User's guide SPIN 3.3 interface}

After starting SPIN from a host-application by clicking the $\cdots$ button next to the substance selection box, the interface substance form is opened. In Figure 2.1 the interface screen is shown when starting SPIN from the host application FOCUSPEARL 5.5.5. The window title bar at the top shows the SPIN version number as well as the name of the host-application. The host application determines the substance properties that need to be specified and only values for the properties required for that application can be entered or modified. Below the title bar the menu bar is shown.

The substance form consists of a 'Browse Substances' section-including the buttons to the right-and the 'Edit Substance' section. When started from a host-application, the browse substances section will show several example substances, which are locked for editing; i.e. the properties cannot be changed and these substances cannot be deleted. These example substances are shown with a lock symbol in the first column of the grid. However, the example substances can be copied and renamed after which the properties can be changed.

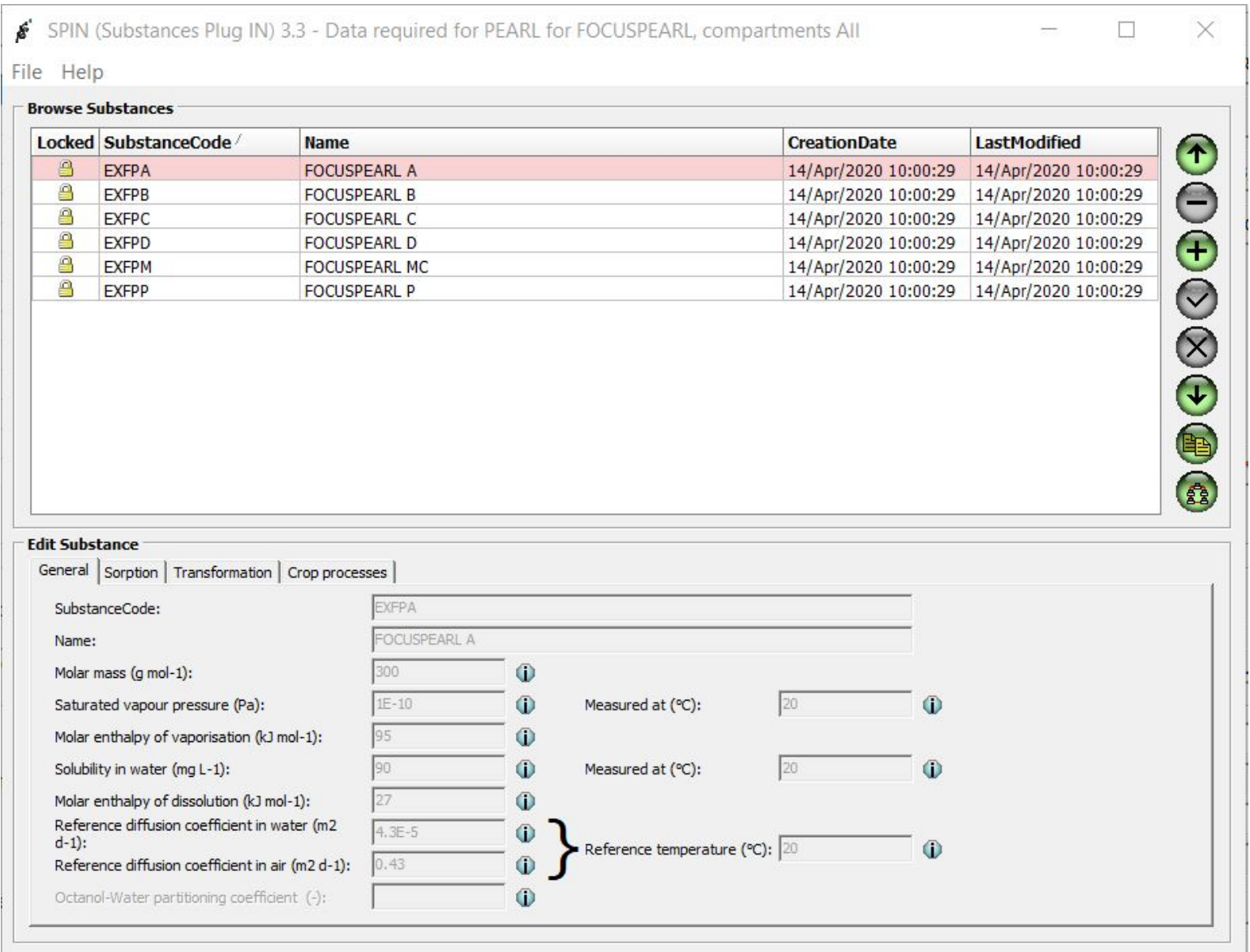

Figure 2.1 Main screen of SPIN 3.3 in combination with the host application FOCUSPEARL.

The menu bar has three menu options:

1. The 'File' menu allows the user to import and export substances and to close the application. Importing and exporting of substances is explained in Section 2.5.

2. The 'Help' menu includes three items:

- "About SPIN (Substances Plug IN)...": opens a window with detailed information about SPIN, including the User Interface version, the database version and the path to the database.

- "Model notes...": opens a window with information about the host-application (if any)

- "SPIN user support...": opens a website where this manual can be downloaded 
3. The 'Edit' menu. This option is only shown in case SPIN is opened as a stand-alone application and allows the user to choose one (or more) host-application(s). After making a selection, the SPIN interface automatically filters the substance properties to those that are required for the host application(s) selected.

\subsection{Management of substances}

In the 'Browse substances' section all substances saved in the database are shown (Figure 2.1). The substances are identified by a unique code and a name. Furthermore, the creation date and the date of the last modification are shown. When starting SPIN from a host application for the first time, a number of example substances, specific for each host-application, will be imported into the SPIN database.

Several buttons exist on the right hand side of the browse substances table; they are explained below:

\begin{tabular}{|l|l|}
\hline( & go to the first substance in the browse substances table \\
\hline$\Theta$ & delete the substance selected in the browse substances table \\
\hline( & create a new substance \\
\hline & save the changes made by the user \\
\hline & cancel the changes made by the user \\
\hline & go to the last substance in the browse substances table \\
\hline & copy the selected substance \\
\hline
\end{tabular}

The buttons are displayed in green when they are active or in grey when they cannot be used. The creation of metabolites (last button) is explained in Section 2.4.

\subsection{Creating a substance}

Creating and copying substances can be done using the "copy the selected substance" button in the Browse substances section (see section 2.1). When entering a new substance or copying an existing substance, the code and the name of the substance have to be specified and must both be unique. The substance code cannot exceed more than 15 characters.

\subsection{Editing a substance}

The 'Edit substance' form is divided in four tabs: General, Sorption, Transformation, and Crop processes. in Figure 2.2 the 'General' tab of this form is shown. 


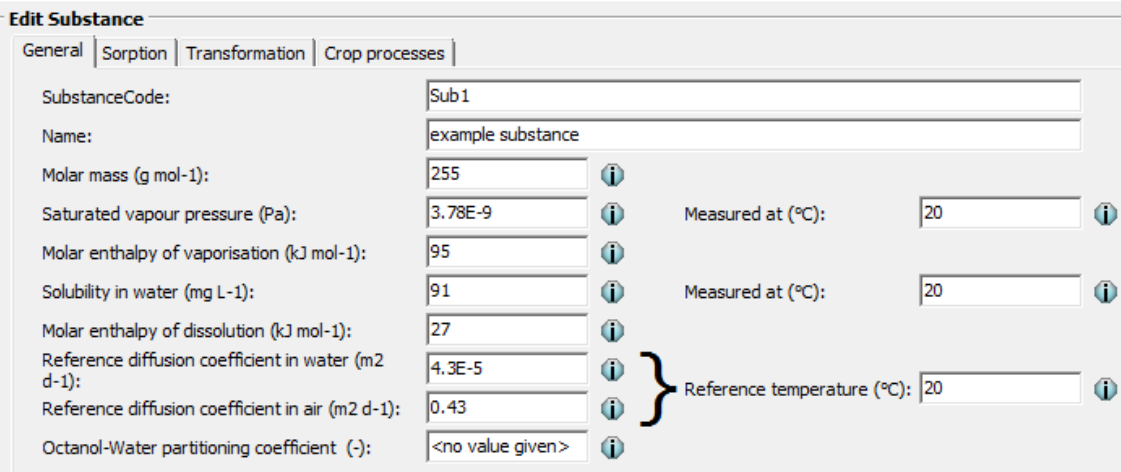

Figure 2.2 The 'Edit Substance' section.

Next to each entry field there is an information button. After clicking on this button information is given about the substance property such as unit, description, minimum and maximum values, the model(s) for which the property is required, and the internal code. An example is shown in Figure 2.3 for the substance property 'Molar mass'.

\begin{tabular}{|c|c|}
\hline \multicolumn{2}{|c|}{ 'Information on "Molar mass" } \\
\hline Unit: & $\mathrm{g} \mathrm{mol-1}$ \\
\hline Description: & Molar mass \\
\hline Minimum value: & 10 \\
\hline Maximum value: & 10000 \\
\hline Required for: & $\begin{array}{l}\text { TOXSWA for FOCUS TOXSWA } 4.4 .2 \text { and higher, MACRO for FOCUS SWASH } 5.3 \text {, } \\
\text { MACRO for FOCUS SWASH } 4.2 \text { and higher, TOXSWA for DRAINBOW and higher, } \\
\text { PEARL for DRAINBOW and higher, PRZM for FOCUS SWASH } 5.3 \text { and higher, } \\
\text { TOXSWA for GEM and higher, Substance emission model for GEM and higher, } \\
\text { PEARL for FOCUSPEARL and higher, PEARL for GEM and higher, GEOPEARL } 4.4 .4 \\
\text { and higher, DROPLET and higher }\end{array}$ \\
\hline Internal name: & MolMass (id =7) \\
\hline
\end{tabular}

Figure 2.3 Example information window for the input parameter 'Molar mass'.

\subsubsection{General tab}

In addition to the name and code of substance, the 'General' tab (see Figure 2.2) lists the following properties:

- molar mass ( $\left.\mathrm{g} \mathrm{mol}^{-1}\right)$;

- saturated vapour pressure $(\mathrm{Pa})$ and the reference temperature at which the vapour pressure has been measured $\left({ }^{\circ} \mathrm{C}\right)$;

- molar enthalpy of vaporisation $\left(\mathrm{kJ} \mathrm{mol}^{-1}\right)$;

- solubility in water $\left.\left(\mathrm{mg} \mathrm{L}^{-1}\right)\right)$ and the reference temperature at which solubility has been measured $\left({ }^{\circ} \mathrm{C}\right)$;

- molar enthalpy of dissolution $\left(\mathrm{kJ} \mathrm{mol}^{-1}\right)$;

- reference diffusion coefficient in water $\left(\mathrm{m}^{2} \mathrm{~d}^{-1}\right)$ and in air $\left(\mathrm{m}^{2} \mathrm{~d}^{-1}\right)$ and the reference temperature at which these values have been measured $\left({ }^{\circ} \mathrm{C}\right)$;

- octanol-water partition coefficient (-).

\subsubsection{Sorption tab}

Under the tab 'Sorption' (Figure 2.4), there are five sub-tabs: Soil-equilibrium, Soil non-equilibrium, Surface water, Sediment and Substrate. 


\section{Soil equilibrium sub-tab}

The 'Soil equilibrium' sub-tab includes properties for three options for sorption in soil: $\mathrm{K}_{\mathrm{f}}$ user defined, $\mathrm{K}_{\mathrm{om}} \mathrm{pH}$-dependent, and $\mathrm{K}_{\mathrm{om}} \mathrm{pH}$-independent. This option can be selected using the option pick-list on the left-hand side of Figure 2.4. Depending on the choice, several additional properties have to be entered: When the option $\mathrm{K}_{\mathrm{f}}$ user defined or $\mathrm{K}_{\mathrm{om}} \mathrm{pH}$-independent is chosen, the corresponding $\mathrm{K}_{\mathrm{f}}\left(\mathrm{kg} \mathrm{L}^{-}\right.$ ${ }^{1}$ ) or $\mathrm{K}_{\mathrm{om}}\left(\mathrm{kg} \mathrm{L}^{-1}\right)$ values have to be entered. When the option $\mathrm{K}_{\mathrm{om}} \mathrm{pH}$-dependent is selected, then the $\mathrm{K}_{\mathrm{om}}$ acid $\left(\mathrm{kg} \mathrm{L}^{-1}\right), \mathrm{K}_{\mathrm{om}}$ base $\left(\mathrm{kg} \mathrm{L}^{-1}\right)$, the $\mathrm{pH}$ correction, and the pKa values have to be entered (Figure 2.5). Furthermore, the temperature at which the sorption coefficients have been measured $\left({ }^{\circ} \mathrm{C}\right)$, the reference concentration in the liquid phase $\left(\mathrm{mg} \mathrm{L}^{-1}\right)$, the molar enthalpy of sorption $\left(\mathrm{kJ} \mathrm{mol}^{-1}\right)$, and the Freundlich sorption exponent can be provided (relevant for FOCUSPEARL and GeoPEARL, but not relevant for FOCUS_SWASH, FOCUS_TOXSWA and DROPLET).

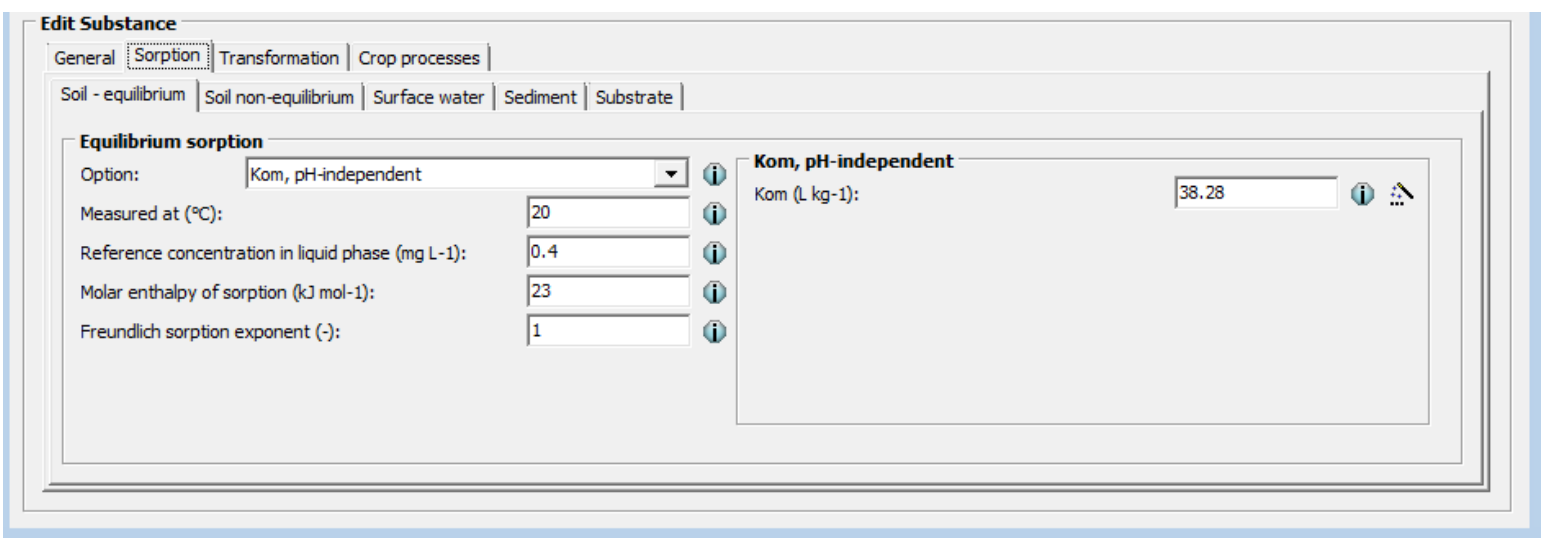

Figure 2.4 Sorption in soil tab; equilibrium sorption sub-tab, pH-independent.

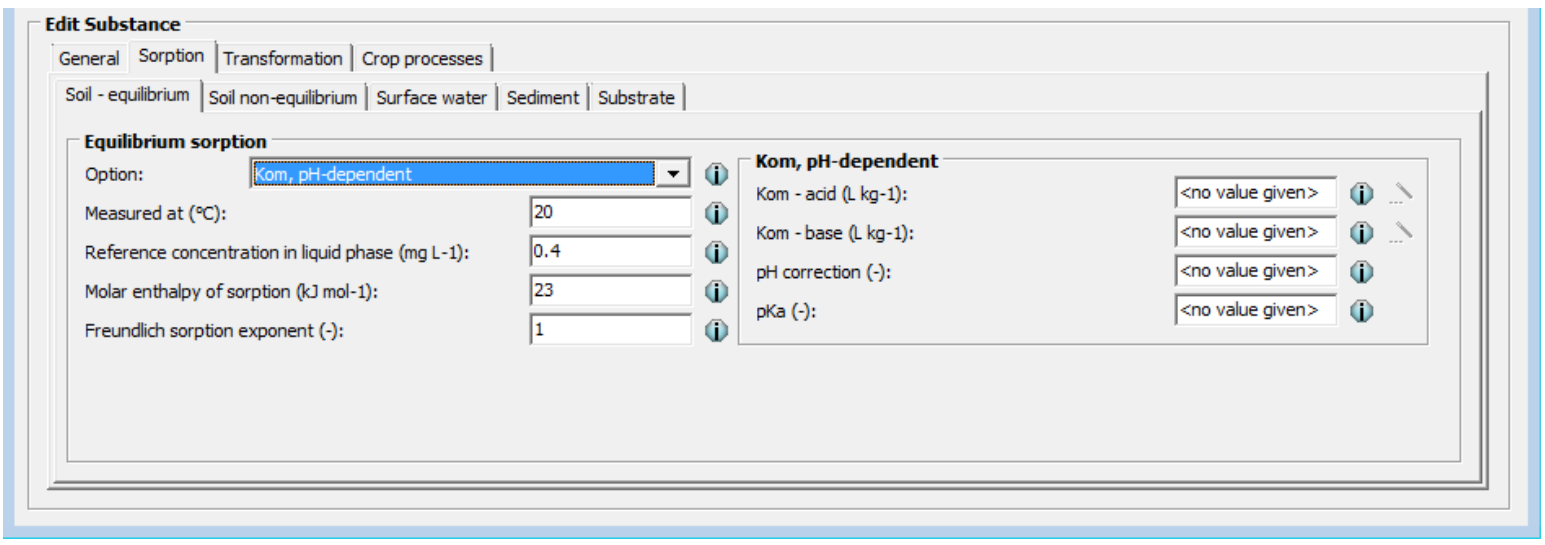

Figure 2.5 Sorption in soil tab; equilibrium sorption sub-tab; option Kom, pH-dependent.

When only the $\mathrm{K}_{\mathrm{oc}}$ value is available for a certain substance, the user can click on the wizard icon, and the "Koc to Kom converter" window will be opened (Figure 2.6). Here the user can enter the Koc value, which will be converted to the Kom value. After clicking on OK the corresponding Kom will be automatically entered in the respective property field. This functionality has been added for the SPIN application in combination with FOCUSSWASH, since the FOCUS Surface Water models require either $\mathrm{K}_{\mathrm{om}}$ or $\mathrm{K}_{\mathrm{oc}}$. It should be noted that the converter button in Figure 2.5 has been greyed out, because in FOCUSPEARL 5.5.5 only $\mathrm{K}_{\mathrm{om}}$ values are required. 


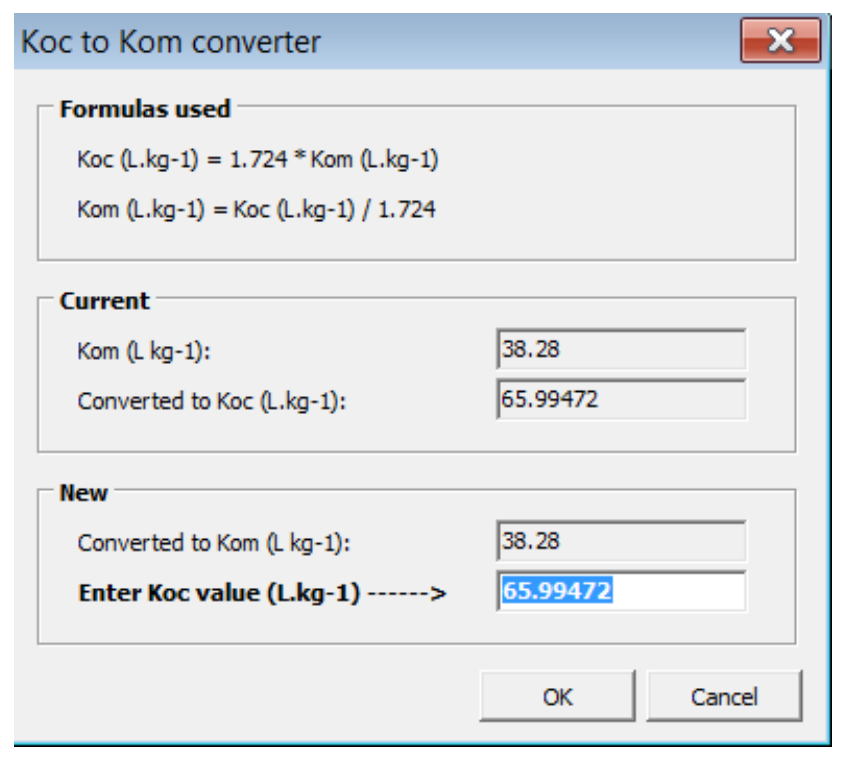

Figure 2.6 The Koc to Kom converter window.

\section{Soil non-equilibrium sub-tab}

On this sub-tab the desorption rate coefficient $\left(\mathrm{d}^{-1}\right)$ and the factor relating the Freundlich coefficient for non-equilibrium sorption and equilibrium sorption can be entered (Figure 2.7). This part is relevant for FOCUSPEARL and GeoPEARL, but not relevant for FOCUSSWASH, FOCUSTOXSWA and DROPLET.

It should be noted that parameters for non-equilibrium sorption parameters can also be specified in FOCUSMACRO and FOCUSPRZM and at present there is no check in SPIN whether the values specified in these models are equivalent with those specified in SPIN for the use of these sorption parameters in combination with FOCUSPEARL or GeoPEARL. The user is recommended to check the consistency of the values used in FOCUSPEARL or GeoPEARL with those in FOCUSMACRO and FOCUSPRZM when necessary.

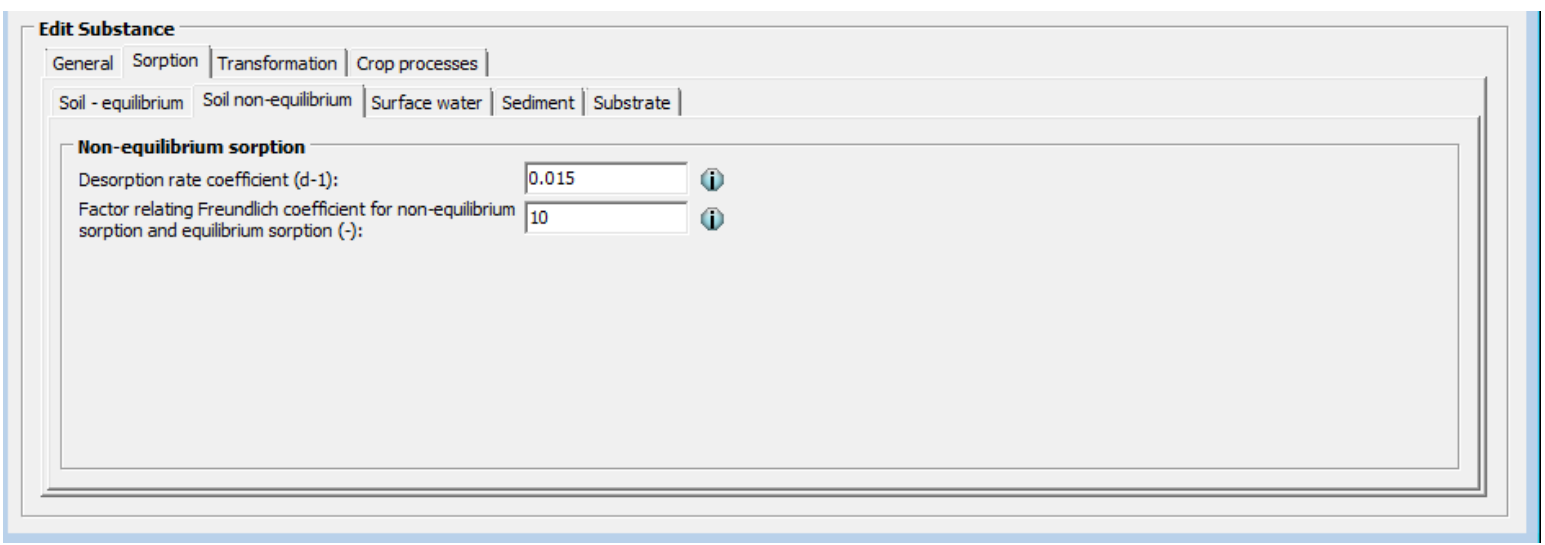

Figure 2.7 Sorption in soil tab; non-equilibrium sorption sub-tab.

\section{Surface water sub-tab}

This sub-tab includes sorption properties in two sections (Figure 2.8). The "Equilibrium sorption in suspended solids" section comprises the $\mathrm{K}_{\mathrm{om}}$ value $\left(\mathrm{L} \mathrm{kg}^{-1}\right)$ for suspended solids as well as the Freundlich sorption exponent (-), and the reference concentration $\left(\mathrm{mg} \mathrm{L}^{-1}\right)$ for this sorption process. Also here, clicking on the wizard symbol opens the "Koc to Kom converter" tool (Figure 2.6).

In the "Equilibrium sorption in macrophytes" section the coefficient for linear sorption on macrophytes $\left(\mathrm{L} \mathrm{kg}^{-1}\right)$ can be set. For this sorption process, a linear sorption isotherm is assumed. 


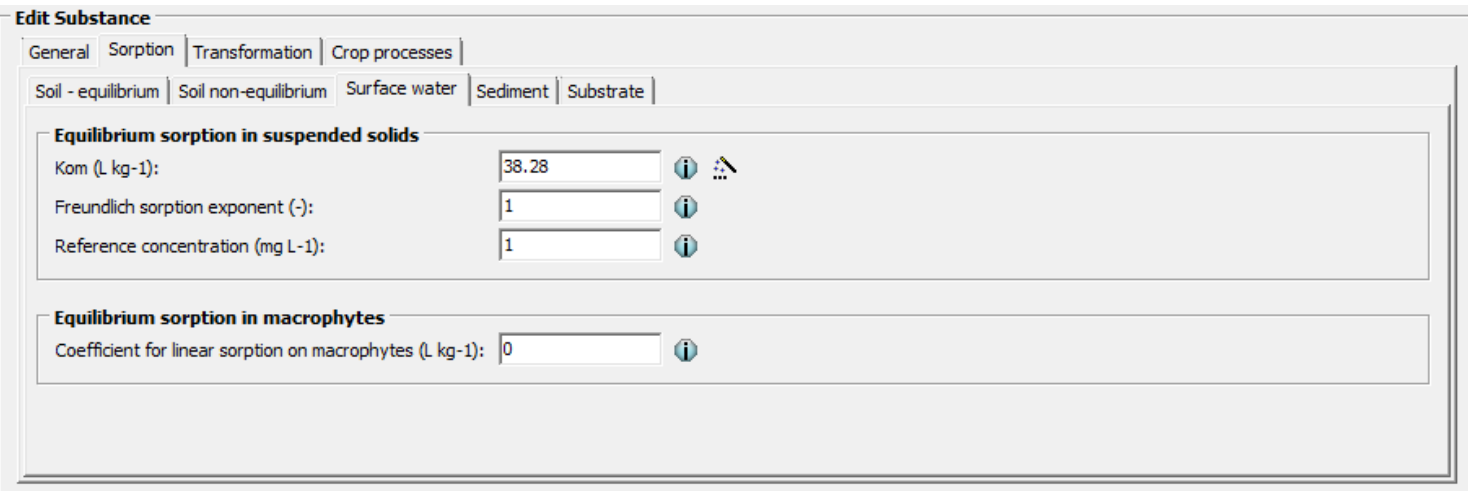

Figure 2.8 Sorption in surface water sub-tab

\section{Sediment sub-tab}

On the 'Sorption - sediment' sub-tab the $\mathrm{K}_{\mathrm{om}}\left(\mathrm{L} \mathrm{kg}^{-1}\right)$ in sediment, the Freundlich sorption exponent and the reference concentration $\left(\mathrm{mg} \mathrm{L}^{-1}\right)$ values can be entered (Figure 2.9). Also here, clicking on the wizard symbol opens the "Koc to Kom converter" tool (Figure 2.6).

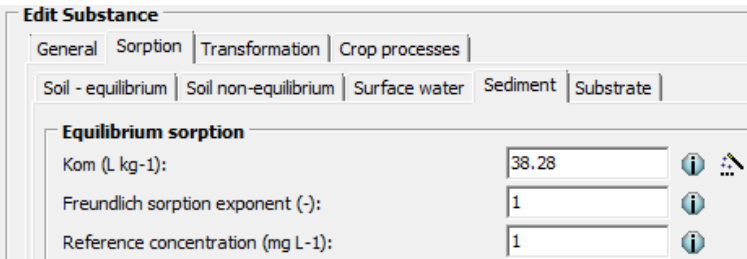

$\begin{array}{ll}\sqrt{38.28} & \text { (i) } \\ \sqrt{1} & \text { i } \\ \text { i } & \end{array}$

Figure 2.9 Sorption in sediment sub-tab.

\section{Substrate sub-tab}

On the 'Substrate' sub-tab the Kom $\left(\mathrm{L} \mathrm{kg}^{-1}\right)$ for sorption on substrate can be entered. The items on this tab are only relevant for the use of SPIN in combination with the Dutch GEM model for the evaluation of the risk of exposure in soil-less greenhouse systems (Figure 2.10)

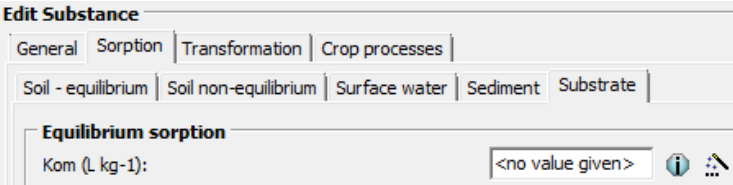

Figure 2.10 Sorption in 'Substrate' sub-tab 


\subsubsection{Transformation tab}

Under the tab 'Transformation' (Figure 2.11) there are seven sub-tabs: 'Soil-aerobic', 'Soil-anaerobic', 'Soil aerobic MACRO\&PRZM', 'Soil - aerobic GeoPEARL', 'Surface water', 'Sediment', and 'Other'.

\section{Soil - aerobic sub-tab}

This sub-tab (see Figure 2.11) includes the following properties:

- half-life of transformation in soil (d) and the temperature at which the half-life has been measured $\left({ }^{\circ} \mathrm{C}\right)$

- molar activation energy $\left(\mathrm{kJ} \mathrm{mol}^{-1}\right)$

- option for moisture conditions

- exponent for the effect of liquid (-)

The option for moisture content depends on the moisture conditions during the transformation study. The moisture conditions may have corresponded to the moisture content at field capacity or wetter or to moisture conditions at pF values greater than 2 (dryer soil conditions). When selecting the latter option the user should enter the liquid content $\left(\mathrm{kg} \mathrm{kg}^{-1}\right)$ of the soil in the incubation experiment.

The exponent for the effect of liquid is the exponent in the relationship developed by Walker (1974).

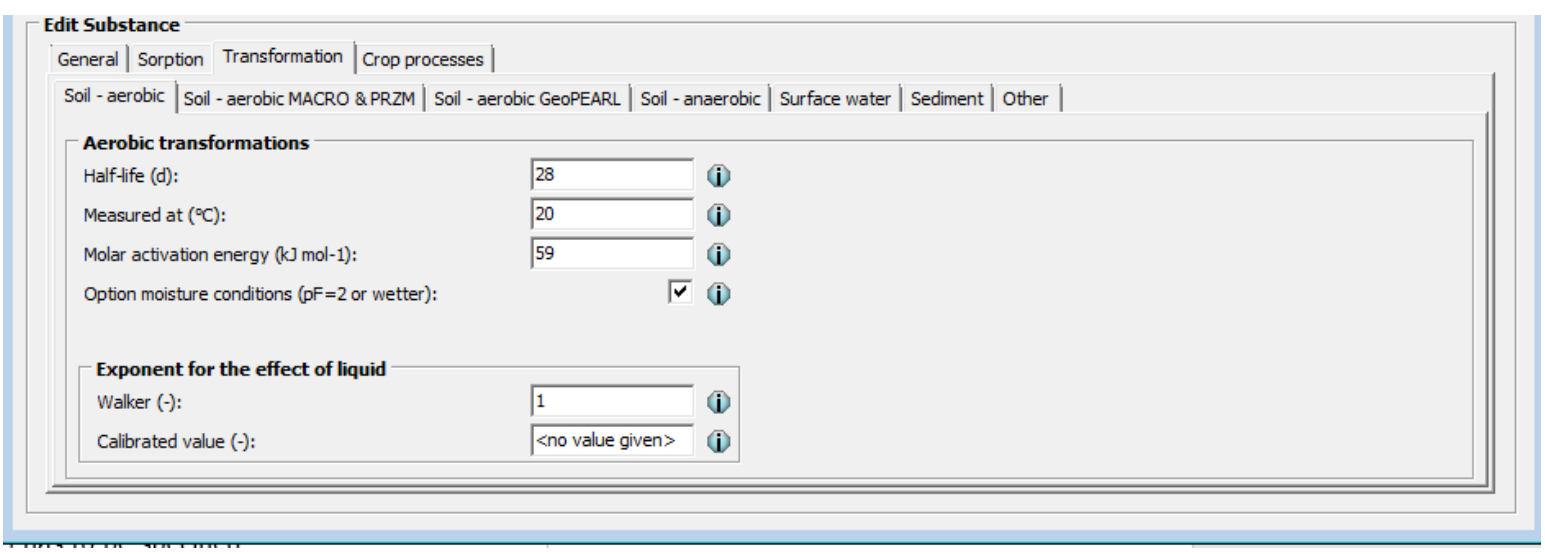

Figure 2.11 Soil-aerobic transformation sub-tab.

\section{Soil - aerobic MACRO\&PRZM sub-tab}

This sub-tab is shown in Figure 2.12 and it includes the following properties:

- a checkbox to include or not include bi-phasic transformation; if selected then the half-life for the second phase of transformation (d) must be specified as well as the number of days after initial application the second phase of transformation begins (d)

- moisture content as measured in transformation study (\%)

- option for moisture content in transformation study (relative to soil or relative to field capacity)

- Q10 factor for the effect of temperature on transformation

- $\mathrm{pF}$ at which DT50 is measured $(\log (\mathrm{cm}))$

- effect of temperature $\left(\mathrm{K}^{-1}\right)$

The items listed in the first four bullet points are required for PRZM and the items in the last two bullet points are required for MACRO.

It should be noted that the molar activation energy, the Q10 factor and the factor for the effect of temperature as used in MACRO all describe the effect of temperature in the same way (FOCUS, 2001). The values to be used in the assessments for the concentrations in surface water using the FOCUS Surface Water scenarios are $65.4 \mathrm{~kJ} \mathrm{~mol}^{-1}, 2.58$ and $0.0948 \mathrm{~K}^{-1}$, respectively. During the installation of FOCUSSWASH an example substance will be imported into SPIN with the correct values for these parameters. 


\section{Edit Substance}

General | Sorption Transformation |Crop processes |

Soil - aerobic Soil -aerobic MACRO \& PRZM | Soil - aerobic GeoPEARL | Soil - anaerobic | Surface water | Sediment | Other |

Option for biphasic transformation:

Half-life of second phase of tranformation (d):

Days after initial application bi-phasic half-life begins (d):

Moisture content (\%) at which half-life is measured (\%):

Option for moisture content in transformation study:

Q10 Factor for effect of temperature on transformation:

$\mathrm{pF}$ at which half-life is measured $(1,2)(\log (\mathrm{cm}))$ :

Effect of temperature $(K-1)$ :

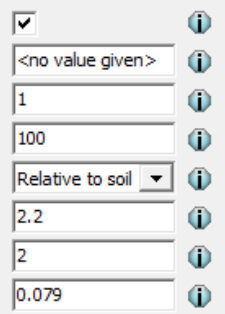

Figure 2.12 Soil-aerobic MACRO\&PRIZM transformation sub-tab.

\section{Soil - aerobic GeoPEARL sub-tab}

The 'Soil-aerobic GeoPEARL - transformation' sub-tab includes transformation properties specific for GeoPEARL. In GeoPEARL, half-life of transformation in soil can either be input by the user or calculated. In SPIN, this option is represented by a dropdown menu. In case "input" is selected, the properties specified on the Soil - aerobic sub-tab are sufficient (Figure 2.13). In case "calculate" is selected, the following additional parameters need to be specified (Figure 2.14):

- $\quad$ minimum half-life $(d)$

- maximum half-life (d)

- Pedotransfer function (PTF) factor for clay fraction (d)

- reference clay fraction $\left(\mathrm{kg} \mathrm{kg}^{-1}\right)$ for PTF

- $\quad$ PTF factor for organic matter (d)

- $\quad$ reference organic matter content $\left(\mathrm{kg} \mathrm{kg}^{-1}\right)$ for PTF

- $\quad$ PTF factor for $\mathrm{pH}(-)$

- $\quad$ reference $\mathrm{pH}$ for PTF

Edit Substance

General | Sorption Transformation |Crop processes |

Soil - aerobic | Soil - aerobic MACRO \& PRZM Soil - aerobic GeoPEARL | Soil - anaerobic | Surface water | Sediment | Other |

Option to describe the half-life of Input
transformation in soil:

The DT50Ref (Half-life (d)) value of the Transformation / Soil - aerobic tab will

be used by GeoPEARL

Figure 2.13 Soil-aerobic GeoPEARL transformation sub-tab; option input.

\begin{tabular}{|c|c|c|c|c|c|}
\hline General| Sorption Transformation | & Crop process & & & & \\
\hline \multicolumn{6}{|c|}{ Soil - aerobic | Soil - aerobic MACRO \& PRZM Soil - aerobic GeoPEARL | Soil -anaerobic | Surface water | Sediment | Other | } \\
\hline \multirow{9}{*}{$\begin{array}{l}\text { Option to describe the half-ife of } \\
\text { transformation in soil: }\end{array}$} & \multirow{9}{*}{\multicolumn{2}{|c|}{ Calculate $\quad$ i }} & Calculate & & \multirow{2}{*}{ (i) } \\
\hline & & & Minimum half life (d): & 25 & \\
\hline & & & Maximum half life (d): & 50 & (i) \\
\hline & & & PTF factor Clay Fraction (d): & 5 & (i) \\
\hline & & & Reference Clay Fraction (kg kg-1): & 1 & (i) \\
\hline & & & PTF factor Organic Matter (d): & 7 & (i) \\
\hline & & & $\begin{array}{l}\text { Reference Organic Matter content for PTF DT50 (kg } \\
\mathrm{kg}-1) \text { : }\end{array}$ & 35 & (i) \\
\hline & & & PTF factor $\mathrm{pH}(\mathrm{d})$ : & 8 & (i) \\
\hline & & & Reference pH (-): & 7 & (i) \\
\hline
\end{tabular}

Figure 2.14 Soil-aerobic GeoPEARL transformation sub-tab; option calculate. 


\section{Soil - anaerobic sub-tab}

The 'Soil anaerobic' sub-tab is shown in Figure 2.15. On this tab the parameters to be specified are:

- the half-life under anaerobic conditions (d)

- the temperature at which the half-life has been was measured $\left({ }^{\circ} \mathrm{C}\right)$

- the molar activation energy $\left(\mathrm{kJ} \mathrm{mol}^{-1}\right)$

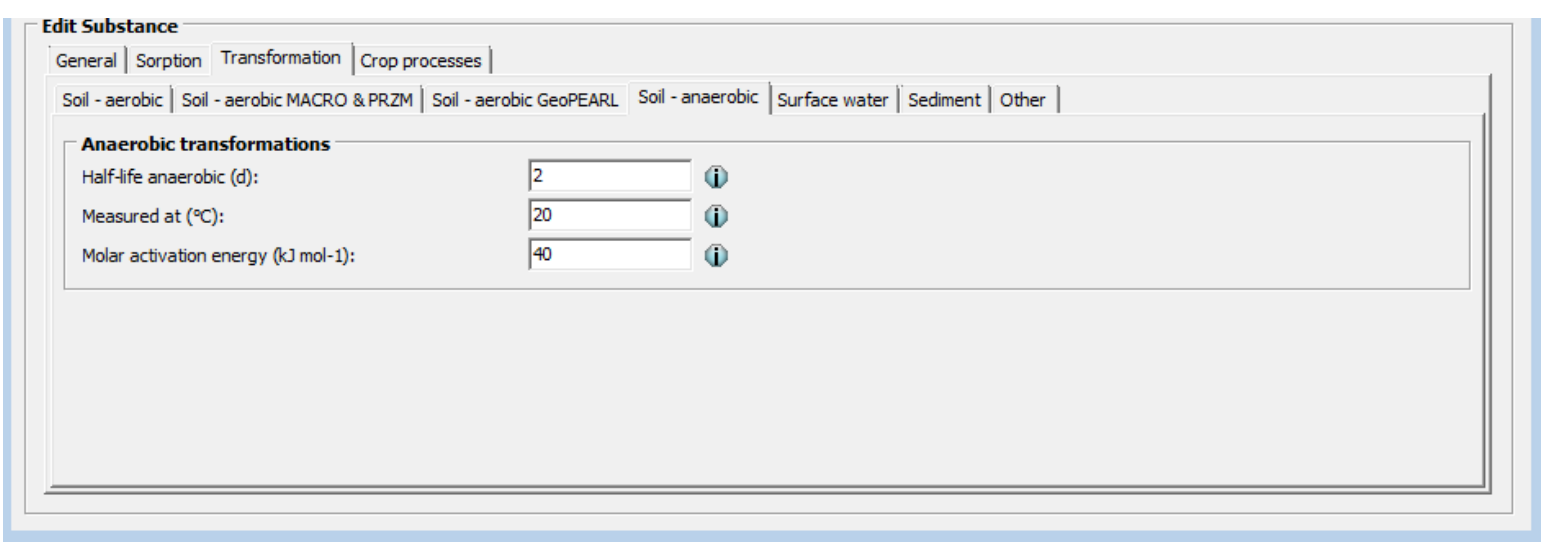

Figure 2.15 Soil-anaerobic transformation sub-tab.

The parameters are only relevant to describe the fate in soil in paddy-rice systems (See Van den Berg et al. 2016).

\section{Surface water sub-tab}

The 'Surface water transformation' sub-tab is presented in Figure 2.16 and it includes properties for the water layer of a water body and the water layer in a paddy field. The latter system is not relevant for the use of SPIN in combination with FOCUS_SWASH or FOCUS_TOXSWA. For the water layer of a water body the parameters to be specified are:

- the half-life for the transformation of the substance in the water layer (d),

- the temperature at which the half-life has been was measured $\left({ }^{\circ} \mathrm{C}\right)$

- the molar activation energy $\left(\mathrm{kJ} \mathrm{mol}^{-1}\right)$.

For the transformation in the water layer of a paddy field only the transformation half-life in this layer is required.

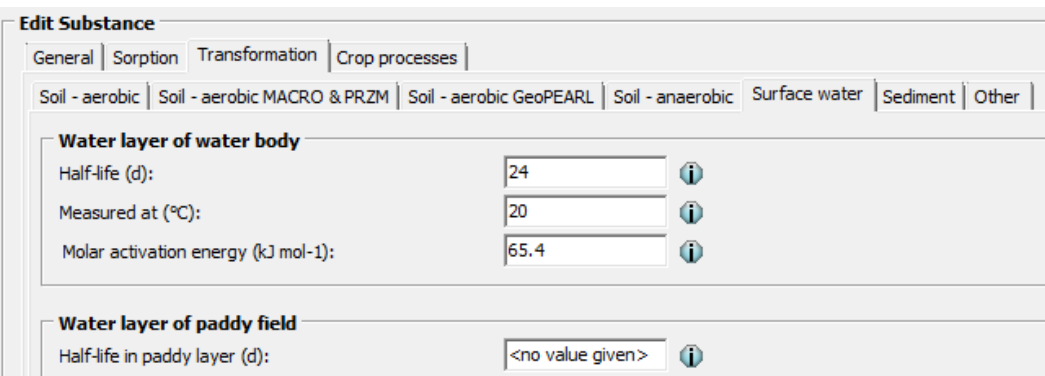

Figure 2.16 The surface water transformation sub-tab.

\section{Sediment sub-tab}

The 'Sediment - transformation' sub-tab is shown in Figure 2.17. On this tab the parameters to be specified are:

- the half-life (d) for the transformation of the substance in the sediment compartment

- the temperature at which the half-life has been measured $\left({ }^{\circ} \mathrm{C}\right)$

- the molar activation energy for the transformation $\left(\mathrm{kJ} \mathrm{mol}^{-1}\right)$. 


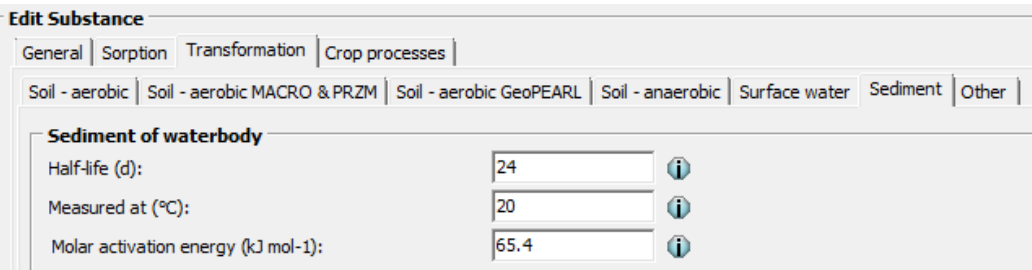

$\sqrt{24}$
$\sqrt{65.4}$ (i)

Figure 2.17 The sediment transformation sub-tab.

\section{Other sub-tab}

The sub-tab 'Other' is shown in (Figure 2.18). The parameters in this tab are only relevant when using SPIN in combination with the GEM model for soilless systems in greenhouses. The parameters to be specified are related to the recirculation water or the greenhouse.

The parameters to be specified for the recirculation water are:

- the half-life (d) in recirculation water

- the temperature $\left({ }^{\circ} \mathrm{C}\right)$ at which the half-life has been measured

- the molar activation energy for the transformation $\left(\mathrm{kJ} \mathrm{mol}^{-1}\right)$

- the half-life for the transformation in the disinfection tank

- the temperature $\left({ }^{\circ} \mathrm{C}\right)$ at which the half-life in the disinfection tank has been measured

The parameters to be specified for the greenhouse are:

- the half-life (d) of the substance deposited on the greenhouse floor

- the half-life (d) of the substance in the greenhouse air

- the half-life (d) of the substance in the substrate

- the temperature $\left({ }^{\circ} \mathrm{C}\right)$ at which the half-lives have been measured

- the molar activation energy for the transformation on the greenhouse floor, the substrate and the greenhouse air $\left(\mathrm{kJ} \mathrm{mol}^{-1}\right)$

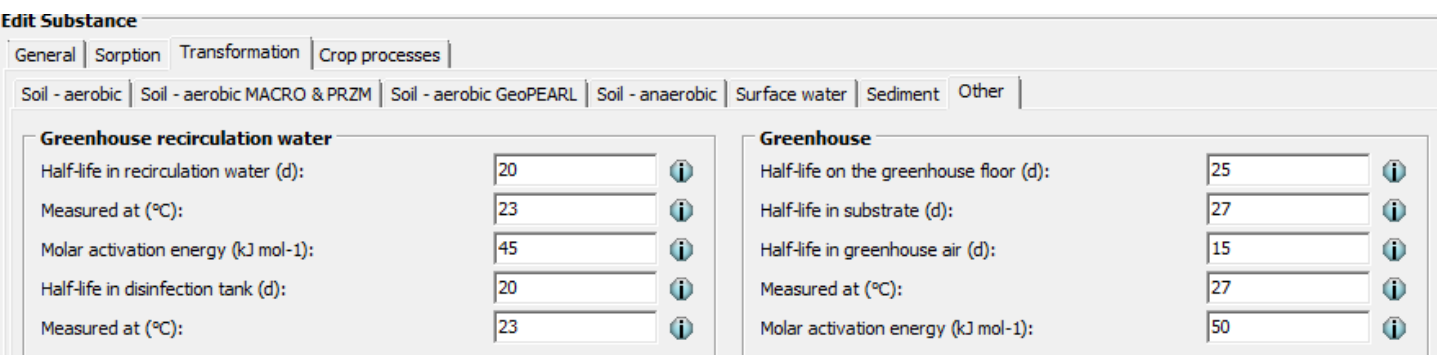

$\sqrt{20}$
$\sqrt{23}$

Figure 2.18 Other transformation sub-tab.

\subsubsection{Crop processes tab}

The 'Crop processes' tab is divided into a 'Canopy' section and a 'Plant root' section and these are shown in Figure 2.19. In the 'Canopy' section the following parameters have to be specified:

- the wash-off factor $\left(\mathrm{m}^{-1}\right)$

- the canopy process option

For the canopy process description the user can select one out of the following three options:

'Lumped', 'Specified' or 'Calculated'. When the option 'Lumped' is selected, then only the half-life of 
dissipation at the crop surface (d) is required. In this case no distinction is made between the possible dissipation pathways, such as photo-transformation or volatilisation. When the option 'Specified' is selected, the half-life values for penetration into the plant leaves, photo-transformation and volatilization (d) have to specified (Figure 2.20). When the option 'Calculated' is chosen, then the halflife values $(d)$ due to penetration and transformation have to be entered. In the latter case the volatilisation rate depends on the prevailing weather conditions.

For FOCUS_SWASH and FOCUS_TOXSWA only the Lumped option can be selected. All three options can be selected when using SPIN in combination with FOCUSPEARL or GeoPEARL.

- In the Plant root section only the coefficient (dimensionless) for uptake by the plant (TSCF) has to be specified. If this parameter is set to zero then no substance is taken up by the plant roots.

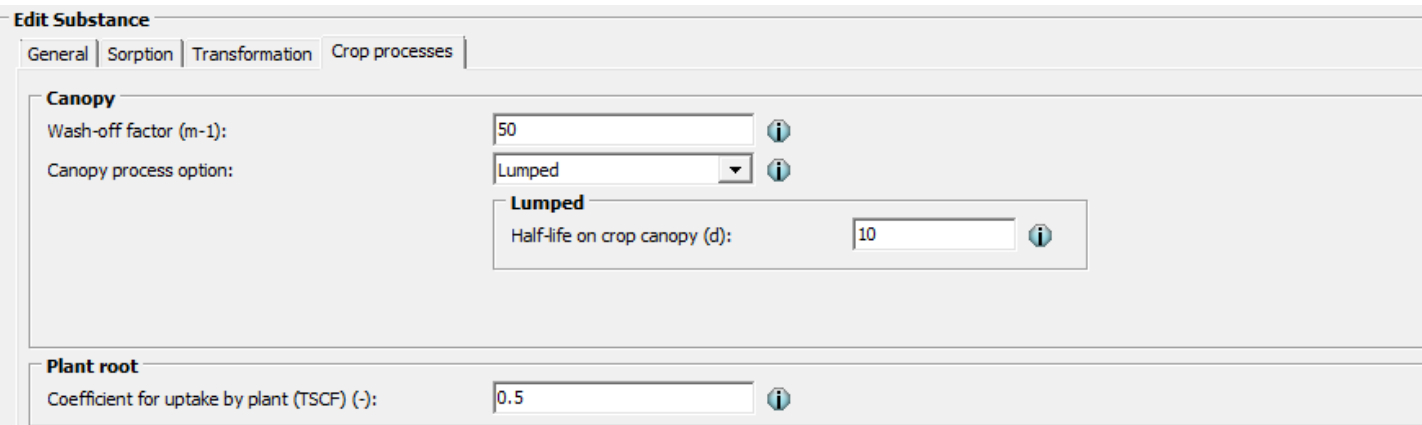

Figure 2.19 Crop processes tab; option: Lumped.

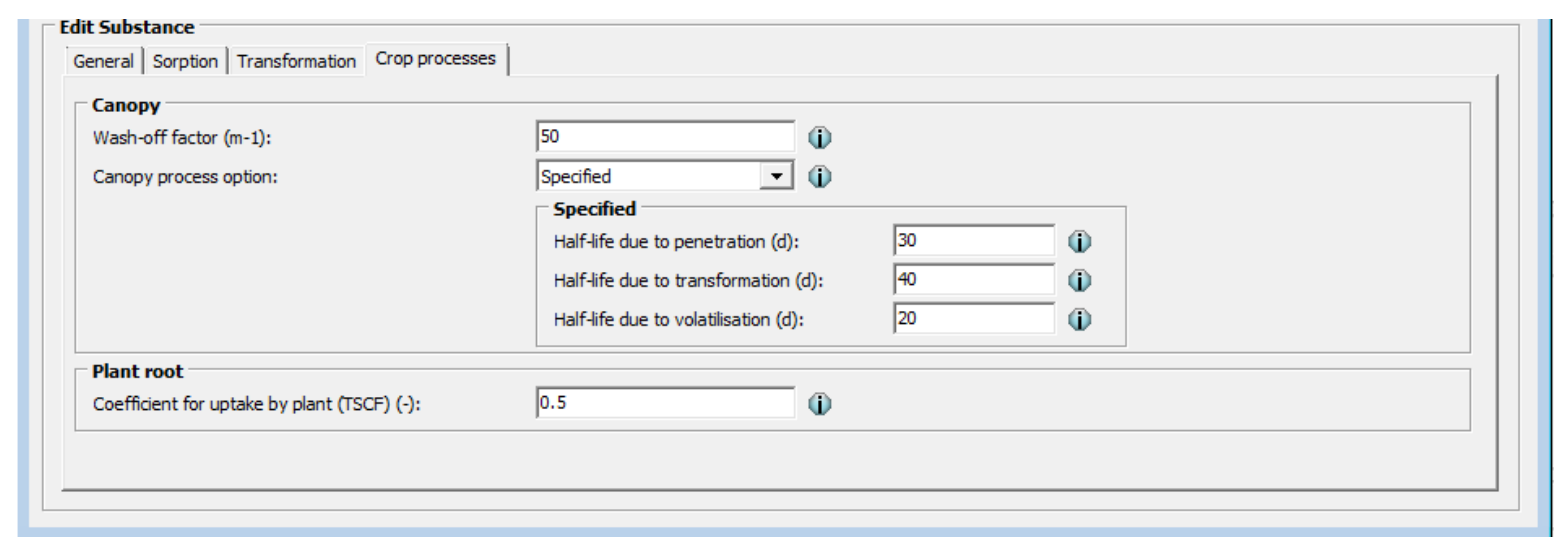

Figure 2.20 Crop processes tab; option: Specified.

\subsection{Creating metabolite schemes}

Metabolites are substances formed by transformation of other (parent) substances. In SPIN this can be specified by linking two substances using the Metabolites form. To link a metabolite (daughter) to a parent substance, first the metabolite substance has to be created as described in section 2.2. Then, the parent substance should be selected in the list of substances shown in the 'Browse substances' part of the SPIN interface. The metabolite window opens by clicking on the open metabolites box symbol, as shown in Figure 2.21. 


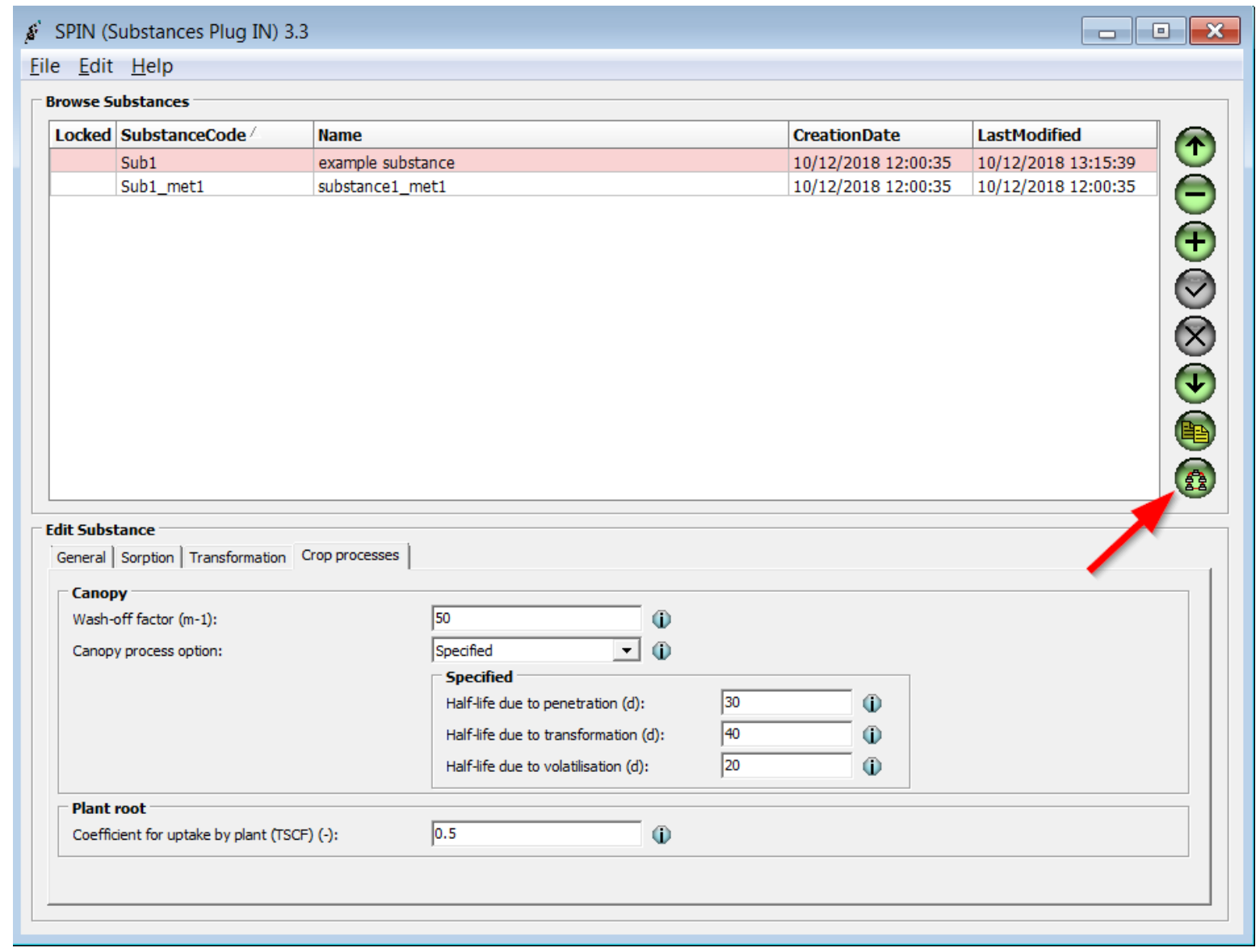

Figure 2.21 The metabolite button provides access to the metabolite form that enables the linking of metabolites to parent substances.

The metabolite window, as shown in Figure 2.22, is divided into four tabs: 'Soil', 'Surface water', 'Sediment' and 'Recirculation water'. These tabs represent the different environmental compartments where the metabolite(s) may be formed. Recirculation water refers to Greenhouses and is only relevant for the use of SPIN in combination with GEM. For FOCUS_SWASH and FOCUS_TOXSWA the 'Soil', 'Surface water' and the 'Sediment' parts are relevant. For the use of SPIN in combination with FOCUSPEARL and GeoPEARL only the 'Soil' part is relevant.

Each tab is consists of two parts:

- the Browse metabolites part. Here, all metabolites associated to a parent substance are shown. The buttons on the right hand-side have the same functionality as described in Section 2.1. The buttons appear in a grey colour when their functionality is disabled, otherwise they appear in green.

- the Edit metabolites part. A metabolite from a drop-down menu can be selected and the fraction transformed can be entered.

The user has to select the appropriate compartment tab, after which the metabolite can be added using the $\bigoplus$ button on the right hand side. Now the user can select the metabolite from the dropdown menu and the molar fraction of the parent substance that is transformed into the metabolite has to be specified. 


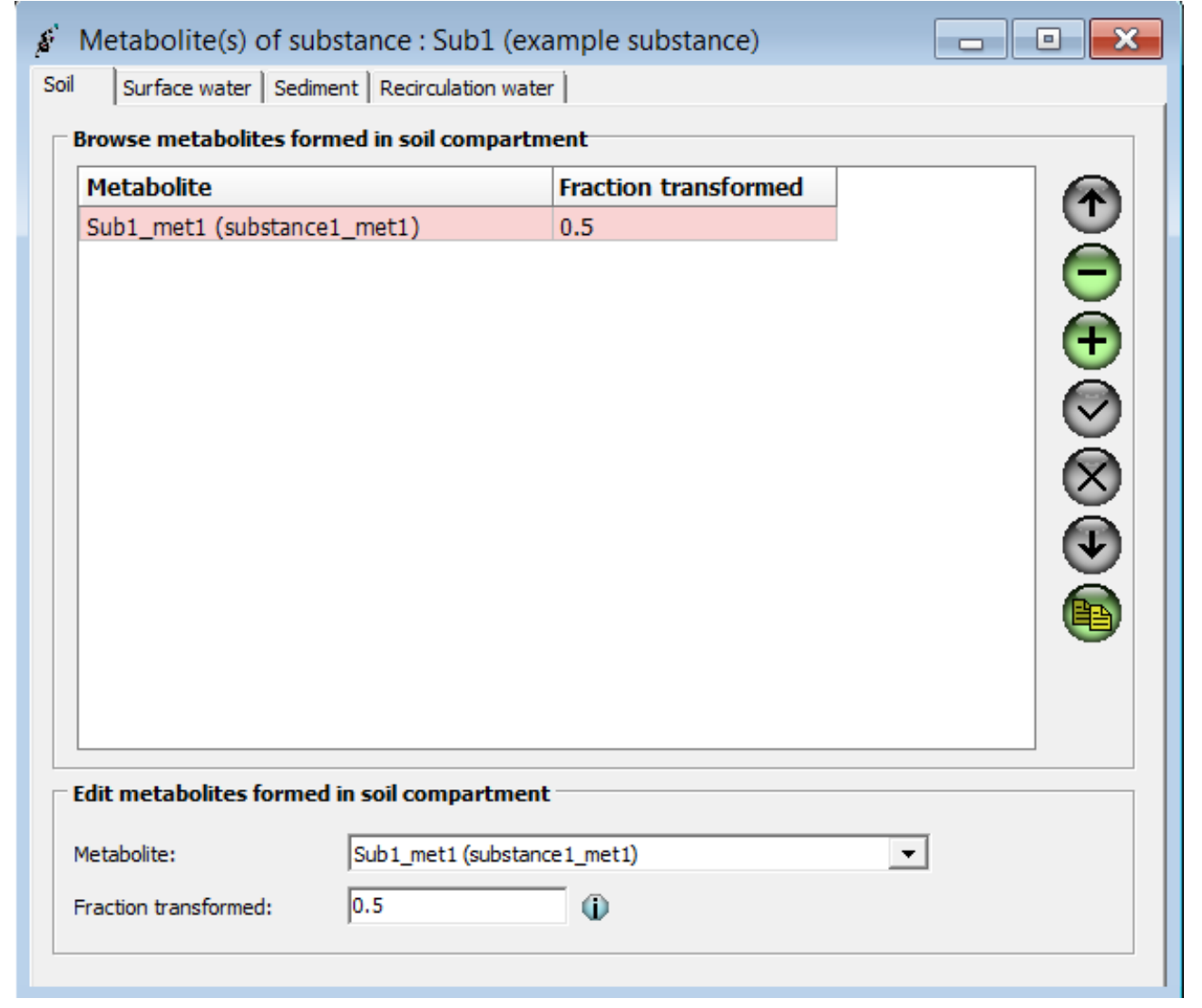

Figure 2.22 The metabolite(s) window. This window enables the creation and editing of metabolites in the compartments Soil, Surface Water, Sediment and Recirculation Water (greenhouses).

For complex metabolite schemes it is advisable to compose a matrix, for each compartment, which represents the links between the substances and the fractions transformed (see example in Table 2.1).

Table 2.1: Example of a matrix which represents the reactions between the compounds included in the reaction scheme of a pesticide. The columns represents the source compound and the rows the receiving compound. $0=$ no reaction. $\chi=$ molar fraction of a compound transformed into a specific product (after van den Berg et al., 2016).

\begin{tabular}{lllllll} 
& Parent & Product 1 & Product 2 & Product 3 & Product 4 & Product 5 \\
Parent & 0 & $\chi_{p, 1}$ & $\chi_{p, 2}$ & 0 & 0 & 0 \\
\hline Product 1 & 0 & 0 & 0 & $\chi_{1,3}$ & $\chi_{1,4}$ & 0 \\
\hline Product 2 & 0 & 0 & 0 & 0 & 0 & 0 \\
\hline Product 3 & 0 & 0 & 0 & 0 & 0 & $\chi_{3,5}$ \\
\hline Product 4 & 0 & 0 & 0 & 0 & 0 & $\chi_{4,5}$ \\
\hline Product 5 & 0 & 0 & 0 & 0 & 0 & 0 \\
\hline
\end{tabular}

\subsection{Export or import substance properties}

SPIN facilitates export and import of substances to and from files.in csv format. In the File Menu on top of the SPIN interface, the user can select 'Export' or 'Import' of substance data. 


\subsubsection{Data export}

After the selection of the Export option the user can choose between the export of substance properties, the export of data on metabolite schemes that are linked to parent substances in the database and the export of substance meta-data (Figure 2.23). The latter consists of a list of all properties in SPIN. For each property, the substance ID, substance name, unit, caption, description, minimum value, maximum value, default value (always empty), and data type (e.g. float, integer, boolean) is given.

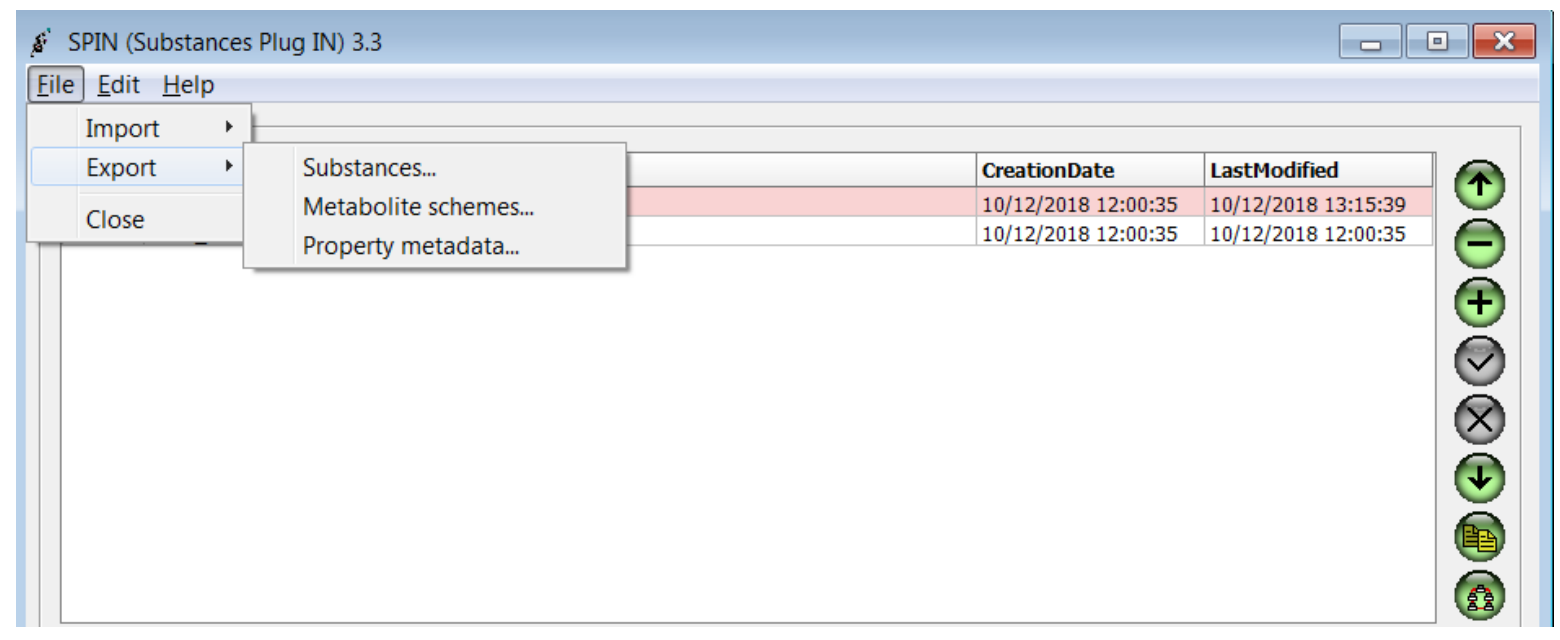

Figure 2.23 Export selection option to export substance properties and metadata.

For the export of substance properties and data on metabolite schemes as well as for the export of metadata, the user may choose the separator between fields and the decimal separator (Figure 2.24). After selection of the separators a window opens to select the export directory and file name.

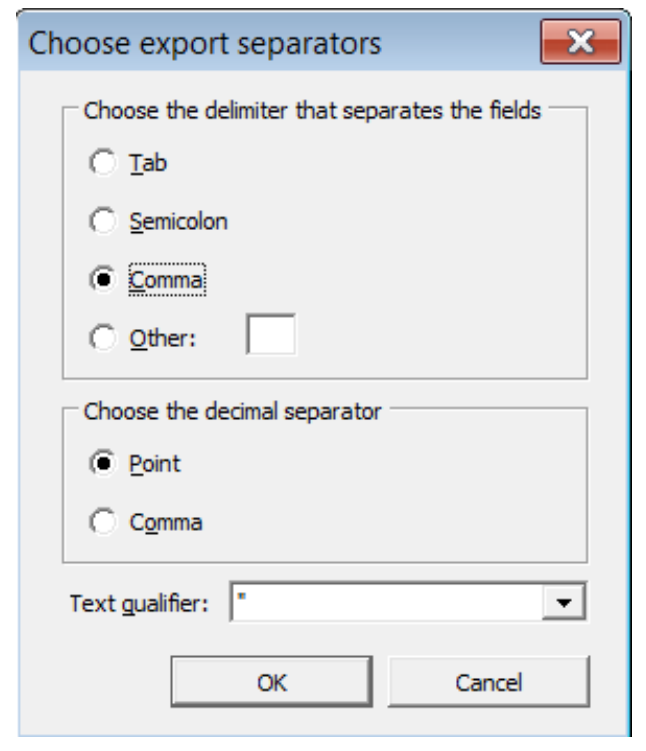

Figure 2.24 The Choose export separator form allows to select the separators.

\subsubsection{Data import}

In the menu, one can select the File / Import / Substances option. A window opens to select the import file. Then a window pops up that enables the delimiter selection and a preview of the interpreted data (Figure 2.25). SPIN checks the validity of the imported data for each field. In case SPIN detects an inconsistency relevant cells are marked in red. 


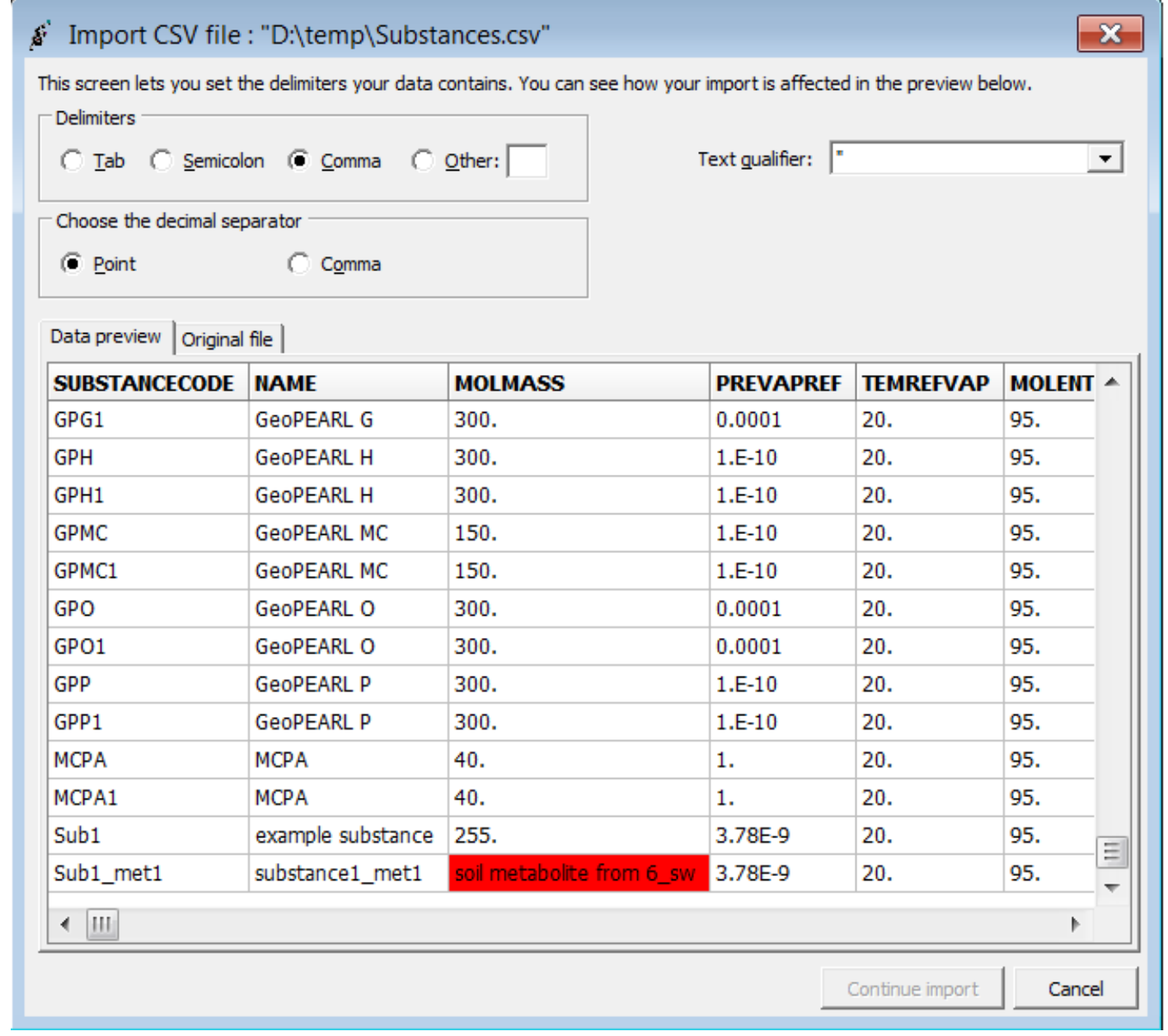

Figure 2.25 The import substances window enables the selection of delimiters and the preview of data. If the data contains errors (red cells) then import is not possible. The button 'Continue import' remains disabled. 



\section{References}

Beltman, W.H.J., M.M.S. ter Horst, P.I. Adriaanse \& A. de Jong (2018). Manual for FOCUS_TOXSWA v5.5.3 and for expert use of TOXSWA kernel v3.3 - User's Guide version 5. WOt-technical report 126. Statutory Research Tasks Unit for Nature \& the Environment, Wageningen, 145 pp.

Berg, F. van den, W.H.J. Beltman, P.I. Adriaanse, A. de Jong \& J.A. te Roller (2015). SWASH Manual 5.3 - User's Guide version 5. WOt-technical report 36. Statutory Research Tasks Unit for Nature \& the Environment, Wageningen, $54 \mathrm{pp}$.

Berg, F. van den, A. Tiktak, J.J.T.I. Boesten \& A.M.A. van der Linden (2016). PEARL model for pesticide behaviour and emission in soil-plant systems. WOt-technical report 61 . Statutory Research Tasks Unit for Nature \& the Environment , Wageningen, 134 pp.

Berg, F. van den, A. Tiktak, D. van Kraalingen \& J.J.T.I. Boesten (2019). User manual for FOCUSPEARL version 5.5.5. Wageningen, the Statutory Research Tasks Unit for Nature \& the Environment (WOT Natuur \& Milieu). WOt-technical report 164. 76 p.

FOCUS (2001). "FOCUS Surface Water Scenarios in the EU Evaluation Process under 91/414/EEC". Report of the FOCUS Working Group on Surface Water Scenarios, EC Document Reference SANCO/4802/2001-rev.2. 245 pp.

Horst, M.M.S. ter, W.H.J. Beltman \& F. van den Berg (2016). The TOXSWA model version 3.3. for pesticide behaviour in small surface waters. WOT-technical report 84. Statutory Research Tasks Unit for Nature \& the Environment, Wageningen, $68 \mathrm{pp}$.

Walker, A., 1974 A simulation model for prediction of herbicide persistence. J. Environ. Qual. 3, 396401. 



\section{Justification}

WOt-technical report: 169

Project: WOT-04-008-024

This manual is an update of the manual for the use of SPIN. The manual had to be updated, because of the need to develop a SPIN version that could be used in combination with the new version of FOCUSPEARL i.e. FOCUSPEARL v 5.5.5. The authors thank Maarten Braakhekke (Wageningen Environmental Research) for his valuable comments on a draft version of this manual. His comments have been used by the authors to make further improvements to this manual.

This project belongs to the WOT theme 'Agri-Environment' with theme leader Erwin van Boekel (WOT Natuur \& Milieu). The project is funded by the Ministry of Agriculture, Nature and Food Quality (project number WOT-04-008-024) with contact person Miranda Meijster.

Approved for publication by external contact person

functie: Senior policy advisor

naam: Miranda Meijster

datum: $\quad 18 / 06 / 2020$

Approved for publication by internal contact person

naam: $\quad$ Erwin van Boekel

datum: $\quad 03 / 06 / 2020$ 



\section{Published documents in the Technical reports series of the Statutory Research Tasks Unit for}

Nature \& the Environment.

146 Arets, E.J.M.M., J.W.H van der Kolk, G.M. Hengeveld, J.P. Lesschen, H. Kramer, P.J. Kuikman \& M.J. Schelhaas (2019). Greenhouse gas reporting of the LULUCF sector in the Netherlands. Methodological background, update 2019.

147 Bruggen, C. van, A. Bannink, C.M. Groenestein, J.F.M. Huijsmans, L.A. Lagerwerf, H.H. Luesink, S.M. van der Sluis, G.L. Velthof \& J. Vonk (2019). Emissies naar lucht uit de landbouw in 2017. Berekeningen met het model NEMA.

148 Lagerwerf, L.A., A. Bannink, C. van Bruggen, C.M. Groenestein, J.F.M. Huijsmans, J.W.H. van der Kolk, H.H. Luesink, S.M. van der Sluis, G.L. Velthof \& J. Vonk (2019). Methodology for estimating emissions from agriculture in the Netherlands. Calculations of $\mathrm{CH} 4, \mathrm{NH} 3, \mathrm{~N} 2 \mathrm{O}$, NOX, NMVOC, PM10, PM2.5 and CO2 with the National Emission Model for Agriculture (NEMA) - update 2019.

149 Bakker, G., M. Heinen, H.P.A. Gooren, W.J.M. de Groot, F.B.T. Assinck \& E.W.J. Hummelink (2019). Hydrofysische gegevens van de bodem in de Basisregistratie Ondergrond (BRO) en het Bodemkundig Informatie Systeem (BIS); Update 2018.

150 IJsseldijk, L.L., M.J.L. Kik, \& A. Gröne (2019). Postmortaal onderzoek van bruinvissen (Phocoena phocoena) uit Nederlandse wateren, 2018. Biologische gegevens, gezondheidsstatus en doodsoorzaken.

151 Daamen, W.P., A.P.P.M. Clerkx \& M.J. Schelhaas (2019). Veldinstructie Zevende Nederlandse Bosinventarisatie (2017-2021); Versie 2.0.

152 Bikker, P., L.B. Šebek, C. van Bruggen \& O. Oenema (2019). Stikstof- en fosfaatexcretie van gangbaar en biologisch gehouden landbouwhuisdieren. Herziening excretieforfaits Meststoffenwet 2019.

153 Berg, F. van den, H. Baveco \& E.L. Wipfler (2019). User manual for SAFE (Select Application date For Evaluation) to support the use of the GEM scenarios for cultivations in glasshouses; Version 1.1

154 Os, J. van, L.J.J. Jeurissen en H.H. Ellen (2019). Rekenregels pluimvee voor de Landbouwtelling; Verantwoording van het gebruik van het Identificatie- \& Registratiesysteem.

155 Brouwer, F. \& D.J.J. Walvoort (2019). Basisregistratie Ondergrond (BRO) Actualisatie bodemkaart; Herkartering van de veengebieden in Eemland

156 Sanders, M.E., R.J.H.G. Henkens \& D.M.E. Slijkerman (2019). Convention on Biological
Diversity; Sixth National Report of the Kingdom of the Netherlands.

157 Kuiters, A.T., G.A. de Groot, D.R. Lammertsma, H.A.H. Jansman, J. Bovenschen, M.C. Boerwinkel \& M. Laar (2019). Genetische monitoring van de Nederlandse otterpopulatie; Ontwikkeling van populatieomvang en genetische status 2018/2019.

158 Sanders, M.E. \& H.A.M. Meeuwsen (2019). Basisbestand Natuur en Landschap.

159 Visser, T., H.A.M Meeuwsen \& Th.C.P. Melman (2019). MNP-(Model for Nature Policy) Agrarisch; Uitwerking voor scenario's uit de Natuurverkenning 2020.

160 Jong, A. de, A. Poot \& P.I. Adriaanse (2019). Impact analysis for the purpose of the introduction of DROPLET version 1.3.2.

161 Westerink, J., T.A. de Boer, M. Pleijte \& R.A.M. Schrijver (2019). Kan een goede boer natuurinclusief zijn?; De rol van culturele normen in een beweging richting natuurinclusieve landbouw.

162 Buijs, A.E., F.G. Boonstra (2020). Natuurbeleid betwist; Visies op legitimiteit en natuurbeleid.

163 Haas, W. de, J.L.M. Donders, T.J.M. Mattijssen (2019). Natuur in conflict; Botsende waarden waarheden en belangen in het natuurbeheer.

164 Berg, F. van den, A. Tiktak, D. van Kraalingen \& J.J.T.I. Boesten (2019). User manual for FOCUSPEARL version 5.5.5.

165 Glorius, S.T., A. Meijboom, J. Schop \& J.T. van der Wal (2019). Ontwikkeling van enkele droogvallende mosselbanken in de Nederlandse Waddenzee; situatie 2018

166 Pedroli, B, During, R. (2019). De paradox van een maakbare natuur - ingebakken en omstreden; Betekenis culturele identiteit voor draagvlak natuurbeleid en -beheer.

167 Walvoort, D.J.J., M. Knotters, F.M. van Egmond (2019). Interpolatie, aggregatie en desaggregatie van ruimtelijke bodemgegevens in de Basisregistratie Ondergrond (BRO).

168 Arets, E.J.M.M., J.W.H van der Kolk, G.M. Hengeveld, J.P. Lesschen, H. Kramer, P.J. Kuikman \& M.J. Schelhaas (2020). Greenhouse gas reporting of the LULUCF sector in the Netherlands. Methodological background, update 2020.

169 Van Kraalingen, D., E.L. Wipfler, F. van den Berg, W.H.J. Beltman, M.M.S. ter Horst \& J.A. te Roller (2020). User manual for FOCUSSPIN version 3.3 
170 Bos-Groenendijk, G.I., C.A.M van Swaay (2020). Habitatrichtlijnrapportage 2019: Annex B Habitatrichtlijnsoorten; Achtergronddocument.

171 Janssen, J.A.M. (red.), R.J. Bijlsma (red.), G.H.P. Arts, M.J. Baptist, S.M. Hennekens, B. de Knegt, T. van der Meij, J.H.J. Schaminée, A.J. van Strien, S. Wijnhoven, T.J.W. Ysebaert (2020). Habitatrichtlijnrapportage 2019: Annex $D$ Habitattypen. Achtergronddocument.

172 Van Kleunen, A., M. van Roomen, E. van Winden, M. Hornman, A. Boele, C. Kampichler, D. Zoetebier, H. Sierdsema \& C. van Turnhout (2020). Vogelrichtlijnrapportage 2013-2018 van Nederland - status en trends van soorten.

173 Glorius, S.T., A. Meijboom (2020). Ontwikkeling van de bodemdiergemeenschap in de geulen van referentiegebied Rottum;

Tussenrapportage 13 jaar na sluiting (najaar 2018).

174 Kuindersma, W., D. van Doren, R. Arnouts, D.A. Kamphorst, J.G. Nuesink, E. de Wit-de Vries (2020). Realisatie Natuurnetwerk door provincies. Achtergrondstudie bij de Tweede Lerende Evaluatie Natuurpact.

175 Bouwma, I.M., D.A. Kamphorst, D. van Doren, T.A. de Boer, A.E. Buijs, C.M. Goossen, J.L.M. Donders, J.Y. Frissel, S. van Broekhoven (2020). Provinciaal beleid voor maatschappelijke betrokkenheid bij natuur het beleid nader bekeken in 8 casussen. Achtergrondstudie bij de Tweede Lerende Evaluatie Natuurpact.

176 Gerritsen, A.L., H. Agricola, C. Aalbers, J. van Os (2020). Natuur en landbouw verbinden. Achtergrondstudie bij de Tweede Lerende Evaluatie Natuurpact.

177 Brouwer, F., D.J.J. Walvoort (2020). Basisregistratie Ondergrond (BRO) Actualisatie bodemkaart. Herkartering van de veengebieden aan de flanken van de Utrechtse Heuvelrug.
178 Bruggen, C. van, A. Bannink, C.M. Groenestein J.F.M. Huijsmans, L.A. Lagerwerf, H.H. Luesink, G.L. Velthof \& J. Vonk (2020). Emissies naar lucht uit de landbouw, 1990-2018; Emissies van ammoniak, stikstofoxide, lachgas, methaan, niet-methaan vluchtige organische stoffen, fijnstof en koolstofdioxide uit kalkmeststoffen - Berekeningen met het model NEMA.

179 Knegt, de B., M. Pleijte, E. de Wit-de Vries, I. Bouwma, F. Kistenkas, W. Nieuwenhuizen (2020). Samenhang Klimaatakkoord en natuurbeleid. Proces en implementatie van het Klimaatakkoord door provincies en maatschappelijke partijen en de potentiële effecten op biodiversiteitsdoelen van de Vogelen Habitatrichtlijn.

180 Mattijssen T.J.M., M. Pleijte, J. Dengerink, T. Koster, M. Visscher (2020). Indicatoren voor burgerbetrokkenheid bij natuur: een zoektocht naar nieuwe aanknopingspunten voor monitoring.

182 Elschot K., M.E.B. Van Puijenbroek, D.D.G. Lagendijk, J-T. Van der Wal, C. Sonneveld (2020). Lange-termijnontwikkeling van kwelders in de Waddenzee (1960-2018).

183 Koffijberg K., P. de Boer, S.C.V. Geelhoed, J. Nienhuis, K. Oosterbeek, J. Postma (2020). Broedsucces van kustbroedvogels in de Waddenzee in 2018

184 IJsseldijk, L.L., M.J.L. Kik, L. van Schalkwijk \& A. Gröne (2020). Postmortaal onderzoek van bruinvissen (Phocoena phocoena) uit Nederlandse wateren, (2019). Biologische gegevens, gezondheidsstatus en doodsoorzaken.

185 Os, J. van, L.J.J. Jeurissen, J.C. Verkaik (2020). Rekenregels schapen en geiten voor de landbouwtelling; Verantwoording van het gebruik van het Identificatie \& Registratiesysteem. 



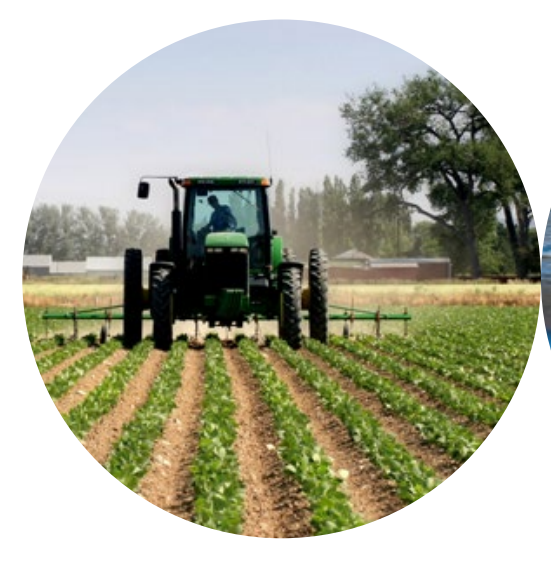

Theme Agri-Environment Wettelijke Onderzoekstaken Natuur \& Milieu

P.O. Box 47

6700 AA Wageningen

T (0317) 485471

E info.wnm@wur.nl

ISSN 2352-2739

www.wur.nl/wotnatuurenmilieu

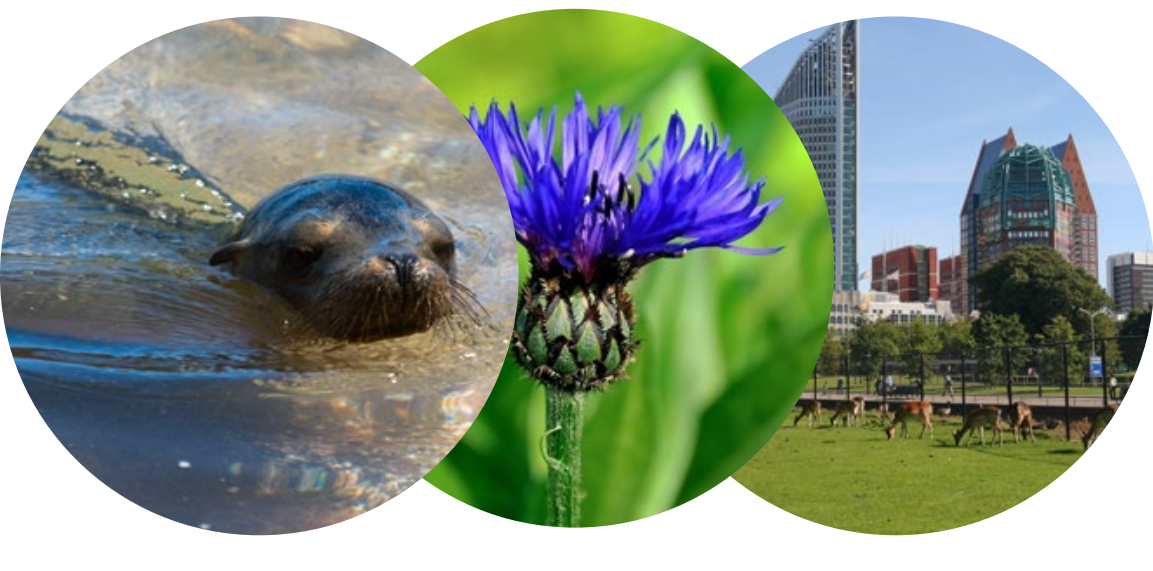

The mission of Wageningen University \& Research is "To explore the potential of nature to improve the quality of life". Under the banner Wageningen University \& Research, Wageningen University and the specialised research institutes of the Wageningen Research Foundation have joined forces in contributing to finding solutions to important questions in the domain of healthy food and living environment. With its roughly 30 branches, 6,500 employees and 12,500 students, Wageningen University \& Research is one of the leading organisations in its domain. The unique Wageningen approach lies in its integrated approach to issues and the collaboration between different disciplines.

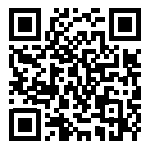

